\title{
シベリア南部ゴルニアルタイ山地のカンブリア紀付加体に 産する古海台/海山頂部起源石灰岩
}

\author{
内尾優 子* 磯 㠃行 雄** BUSLOV, Mikhail *** \\ 太田努* 宇都宮敦* 丸山茂 徳*
}

\section{Paleo-plateau / -seamount Limestone of the Cambrian Accretionary Complex in the Gorny Altai Mountains, Southern Siberia}

Yuko UCHIO *, Yukio ISOZAKI**, Mikhail M. BUSLOV***, Tsutomu OTA*, Atsushi UTSUNOMIYA * and Shigenori MARUYAMA *

\begin{abstract}
Vendian-Cambrian Baratal limestone occurs as large allochthonous blocks in the Cambrian accretionary complex of the Gorny Altai Mountains, southern Russia. We analyzed the primary stratigraphy and depositional environments of Baratal limestone in the Kurai and Akkaya areas in the eastern part of the Gorny Altai Mountains.

In the Kurai and the Akkaya areas, Baratal limestone conformably overlies basaltic greenstone. Geochemistry of this greenstone is similar to that found in modern oceanic plateau basalt or oceanic island basalt. The limestone lacks terrigeneous clastic influx. These suggest that the Baratal limestone was originally deposited on and around a plateau or seamount far from the continents in a mid-oceanic environment.

Baratal limestone in the study area is lithologically divided into four types; 1) massive lime mudstone, 2) massive limestone conglomerate 3) bedded lime mudstone with slump structures, and 4) laminated lime mudstone. Massive lime mudstone contains stromatolites and ooids. This evidence suggests that the massive lime mudstone was formed in a shallowmarine environment. The massive limestone conglomerate contains angular clasts of lime mudstone, greenstone and chert. Its poorly graded and poorly sorted characteristics suggest that the limestone conglomerate was formed as debris flow deposits. Some parts of bedded lime mudstone have slump structures, and are interpreted as sliding deposits. In addition, laminated lime mudstone that shares an affinity with limestone turbidite, is associated with the massive limestone conglomerate.
\end{abstract}

Sedimentary environments of these four types of limestone are inferred, respectively as

\footnotetext{
* 東京工業大学大学院理工学研究科地球惑星科学専攻

** 東京大学大学院総合文化研究科広域システム科学系宇宙地球科学教室

*** ロシア科学院総合地質研究所 シベリア支局

* Department of Earth and Planetary Science, Graduate School of Science and Engineering, Tokyo Institute of Technology

** Department of Earth Science and Astronomy, Graduate School of Arts and Sciences, University of Tokyo

*** United Institute of Geology, Geophysics and Mineralogy, Siberian Branch of Russian Academy of Science
} 
follows; massive lime mudstone may have been diposited on the top of a paleo-plateau/ -seamount, while massive limestone conglomerate, bedded lime mudstone with slump structures, and laminated lime mudstone on the slope of a paleo-plateau/-seamount.

Key words: Cambrian, accretionary complex, paleo-plateau/-seamount, limestone, Gorny Altai Mountains

キーワード：カンブリア紀, 付加体, 古海台/海山, 石灰岩, ゴルニアルタイ山地

\section{I. はじめに}

現世海洋には，2 億年前以前の過去の海洋の痕 跡は残されていない。失われた過去の海洋環境を 探る研究視点および解析手法は, 日本における古 生代・中生代付加体中のチャートや石灰岩の研究 を通して開発されてきた。日本の古生代・中生代 付加体中には, 海洋地款起源の立武岩質緑色岩, チャート・石灰岩などの遠洋性生物源堆積岩が多 数含まれる（Isozaki et al., 1990 など）。中でも， 海山の山体を形成していたと考えられる玄武岩質 溶岩および火山砕屑岩由来の緑色岩と, 礁成石灰 岩（太田, 1968; 長谷ほか, 1974 など）が密接な 産状関係を持つことから，付加体中の石灰岩の多 くはもともと古海山頂部に発達した炭酸塩プラット フォームであったと判断されている（Kanmera and Nishi, 1983 など)。そのため海洋の中央部で 堆積した古海山頂部起源の石死岩は, 過去の海洋 中央部の環境復元に際しての重要な情報源となる。 このような視点から付加体中の古海山起源石灰岩 を用いて，過去のグローバルな環境変化を解読す る試みが，例えば古生代・中生代境界事件につい て始められている（磯㟝, 1997; 太田ほか, 2000 など)。

ロシアのシベリア南部, モンゴルとの国境に位 置するゴルニアルタイ（Gorny Altai）山地には, 古生代造山带が発達する。その中央部には, カン ブリア紀付加体が分布する（Buslov et al., 1993; Sengör and Natalin, 1996: 図 1)。この付加体中 には原生代末ベンド紀〜古生代初期カンブリア紀 とされる石灰岩が含まれ（Zybin and Sergeev， 1978），それらは古海山頂部に堆積した可能性が
指摘されている(内尾ほか, 1998)。しかし，これ らの石灰岩はほとんど化石を産出せず，また一部 は強い変成作用および変形を被っているため, 石 灰岩の層序および年代の詳細はこれまでほとんど 明らかにされていない。

本研究では，カンブリア紀付加体中に産する石 灰岩の初生層序の解析と堆積場の検討を行ない, ベンド紀〜カンブリア紀頃の古海山頂部の炭酸塩 複合体の復元を試みる。筆者らは, 1998 年から 2001 年の 4 年間，いずれも夏期にゴルニアルタイ 山地の南東部クライ（Kurai）地域およびアッカ ヤ（Akkaya）地域を訪れ，合計約 60 日間の野外 調査および岩石試料採取を行なった。その結果, これらの石灰岩が付加体の一部として取り込まれ る以前の, 古海洋中央部で堆積した際の初生層序 を解明した。この新知見は, 同地域の付加体の起 源や形成過程を解明する上での重要な判断材料と なるのみならず, 当時の古海洋の復元の上で重要 である。さらに, 生物相の大変革が起きた原生代/ 古生代境界の研究に, 従来とは全く異なる視点と 理解をもたらすことも期待される。

本稿では，ゴルニアルタイ山地の付加体に産す る石灰岩の産状, 層序および岩相について記載し, その初生的な形成場の復元および堆積環境に関す る考察を試みる。とくに，付加体中の緑色岩およ び石灰岩が, 過去の海台/海山およびその頂部の炭 酸塩プラットフォームの一部であったことを議論 する。なお，本研究の成果からもたらされる原生 代/古生代境界での環境変化についての新知見や その考察は別途報告する。 


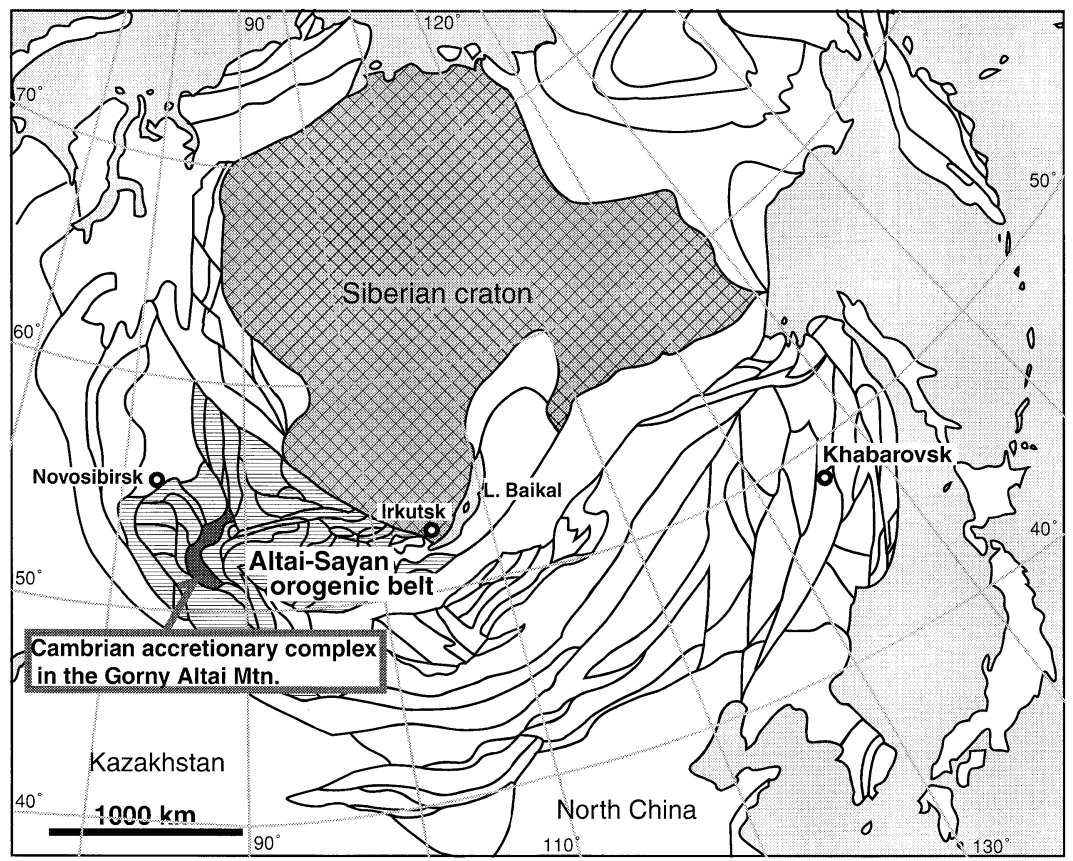

図 1 ロシア, ゴルニアルタイ山地の調査地域位置図. (Sengör and Natalin, 1996 を改変)

害線は，各種地質体間の境界を示す。アルタイ・サヤン造山带を横縞で， ゴルニアルタイ山地のカンブリア紀付加体を黒色で示す.

Fig. 1 Index map of the study area in the Gorny Altai Mountains, Russia. (compiled from Sengör and Natalin, 1996)

Solid lines indicate boundaries among geological units. Areas with horizontal stripes and solid black indicate the Altai-Sayan orogenic belt and the Cambrian accertionary complex in the Gorny Altai Mountains, respectively.

\section{II. ゴルニアルタイ山地の地質概説}

シベリア地塊は，主に先カンブリア時代の地質 体からなる安定地塊の 1 つであり，その南西縁に は全長およそ $5,000 \mathrm{~km}$, 幅 $1,500 \mathrm{~km}$ の古生代一 中生代造山帯が発達する (図 1; Maruyama et al., 1989; Sengör and Natalin, 1996 など)。カザフ スタンからシベリア南部を経て, 中国北部に至る この造山帯を，かつてE. Suess は Altaides と呼 んだが，その後 Argand（1924）ほかはその内部 を複数の造山帯として区分した。最近では，とく にその中央部を Altai-Sayan 造山帯と呼ぶことが 多い (Zonenshain, 1973; Sengör and Natalin, 1996）。同造山带には，原生代末リフィ紀から古
生代石炭紀にかけての付加体起源の低温高圧型変 成岩, オフィオライト, 前弧盆堆積物, 島弧の深 成岩・灭山岩などが分布する。各地質体は主に北 西一南東方向に延びる狭長な帯をなし, 一部は東に 開いた「くの字」形の屈曲した分布を持つ。

本研究の調查地であるゴルニアルタイ山地は 一辺が約 $500 \mathrm{~km}$ のほぼ正三角形の形をなし， Altai-Sayan 造山带のほぼ中央部に位置する（図 2 右上の図, 参照)。Buslov et al. (1993)や Buslov and Watanabe (1996) は，ゴルニアルタイ山地 を広域に調查し，同地域の地質概要を初めてプ レート造山論的視点から説明した。その中で，べ ンド紀ーカンブリア紀の弱変成付加体, ベンド紀カンブリア紀の低温高圧型変成岩, ベンド紀-カン 


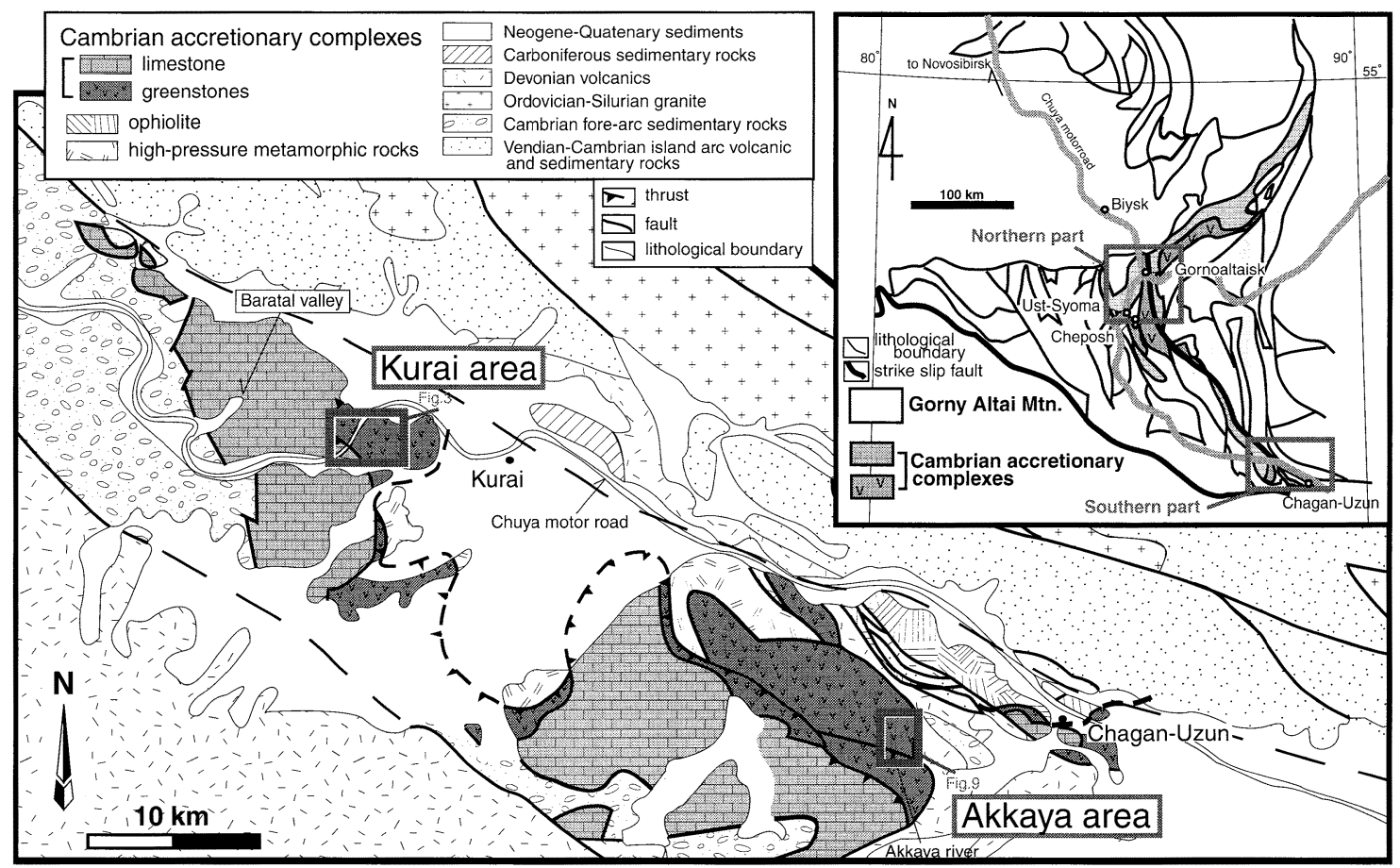

図 2 ゴルニアルタイ山地のカンブリア紀付加体の分布図および同山地南部の地質概略図. (Buslov et al., 1993 を改変)

Fig. 2 Index map of the Cambrian accretionary complex in the Gorny Altai Mountains and geologic sketch map of its southern part. (modified from Buslov et al., 1993)

ブリア紀オフィオライト, ベンド紀-デボン紀の 島弧火山岩類, およびカンブリア紀から石炭紀の 前弧盆堆積物などの, 過去の海洋プレート沈み込 みで形成されたコルディエラ型あるいは都城型造 山運動の産物が同山地に分布することを初めて指 摘した。

カンブリア紀付加体は, ゴルニアルタイ山地の 中央部の南北約 $400 \mathrm{~km}$, 東西約 $70 \mathrm{~km}$ に及ぶ狭 長な分布域を持つ（図 2)。同付加体は，主に玄武 岩質緑色岩類, 石灰岩, 砂岩・泥岩および少量の チャートや縩岩から構成される。緑色岩類や石灰 岩は砕屑岩中の異地性岩体として産する。これら の付加体構成岩の大部分は, 緑色片岩相ないしそ れ以下の弱い広域変成作用を被っているが, 強い 変形は認められない。これらの弱変成岩の付加体 としての形成年代は, 磂岩中の石灰岩円礫から産 するカンブリア紀古盃類化石 (Buslov et al.,
1993）に基づき，カンブリア紀ないしそれ以降で あると推定される。

Buslov et al.（1993）は，岩相組み合わせに基 づきカンブリア紀付加体を二分し, 石灰岩や チャートが卓越する部分を Baratal suite と, また 玄武岩質火山挽屑岩を主とし，一部炭酸塩岩をブ ロックとして含有する部分を Manzherok suite と呼んだ。

上述の弱変成付加体と断層で境されて, 隣接し て低温高圧型変成岩が産する。主に塩基性および 泥質の結晶片岩からなり, パンペリー石ーアクチノ 閃石相, 藍閃石片岩一緑色片岩相から角閃岩相に及 ぶ変成鉱物組み合わせを持つ。カンラン岩, 変班 れい岩および蛇紋岩を伴う。蛇紋岩中にはブロッ ク状のエクロジャイト（角閃石 $\mathrm{K}-\mathrm{Ar}$ 年代 $535 \pm$ $24 \mathrm{Ma}$; カンブリア紀前期), ザクロ石角閃岩（角 閃石 $\mathrm{K}-\mathrm{Ar}$ 年代 $473 \pm 13 \mathrm{Ma}$ および $487 \pm 22$ 
$\mathrm{Ma}$; オルドビス紀), および角閃岩 (角閃石 K-Ar 年代 $523 \pm 23 \mathrm{Ma}$; カンブリア紀前期）が産する (Buslov and Watanabe, 1996)。また, 蛇紋岩中 の緑泥石および緑泥石一白雲母混合物の K-Ar 年代 は, $540 \pm 24 \mathrm{Ma}$; カンブリア紀初期, および $567 \pm 11 \mathrm{Ma}$;ベンド紀末を示した（Buslov and Watanabe, 1996)。

\section{III. カンブリア紀付加体中の緑色岩・石灰岩}

\section{1）玄武岩質緑色岩類}

ゴルニアルタイ山地北部の Gornoaltaisk 市周 辺地域と, 南東部の Kurai/Chagan-Uzun 地域周 辺の 2 地域には, カンブリア紀弱変成付加体が 広く分布する（図 2)。とくに同山地北部，UstSyoma 集落と Cheposh 集落の間の Katun 川流域 （図 2 右上の挿入図）には, Buslov et al. (1993) が Manzherok suite と呼んだ緑色岩類を主とす る付加体が広く露出する。この付加体は, 主に玄 武岩質溶岩および火山砕屑岩を原岩とする緑色岩 類からなり, 長径 $100 \mathrm{~m}$ 以下の石灰岩, ドロマイ トおよびチャートのブロックを多数含む。見かけ 上の層厚は約 $1,000 \mathrm{~m}$ に達する。この緑色岩類の 一部は, $\left(\mathrm{Na}_{2} \mathrm{O}+\mathrm{K}_{2} \mathrm{O}\right)$ 量の多いソレアイト質玄武 岩を原岩とすることから, 北部地域の緑色岩類 は海洋島玄武岩に由来すると推定されている (Buslov et al., 1993)。

上述の北部地域から約 $300 \mathrm{~km}$ 南方に位置する, ゴルニアルタイ山地南東部の Kurai 集落周辺（ク ライ地域）（図 2）およびAkkaya 川流域（アッカ ヤ地域）（図 2）にも緑色岩類を主とする弱変成の 付加体が分布する。その層厚は約 $1,400 \mathrm{~m}$ である。 Zybin and Sergeev (1978)によって, Arydhzan suiteあるいはSagalak suite と呼ばれたクライ地 域およびアッカヤ地域の玄武岩質緑色岩類は, 北 部地域の例と同様に現世の海洋島玄武岩に近い主 成分化学組成を持ち，また部分的には，現世の中 央海嶺玄武岩に類似する組成を持つ部分も伴う (Gusev, 1991; Buslov et al., 1993)。南部地域の 緑色岩類は, いずれも地体構造上の連続性から上 述の北部地域 Katun 川流域の Manzherok suite の南方延長と判断される。

\section{2) 石灰岩}

Zybin and Sergeev (1978) およびBuslov et al. （1993）は，ゴルニアルタイ山地南東部の Baratal 渓谷付近に大規模に露出し, 見かけの層厚が $1,800 \mathrm{~m}$ に達する石灰岩をカンブリア紀付加体の 一部とみなし (図 2), この石灰岩体を Baratal suite と呼んだ。Baratal suite は主に石灰岩からなり, 一部にドロマイト化した石灰岩, 珪質な石灰岩を 含む。

同山地南部のアッカヤ地域にも，類似した岩相 の石灰岩が分布する。地体構造上, Baratal 渓谷 付近の石灰岩と連続すること，また岩相が類似す ることから，この地域の石灰岩も同一の起源を 持つとみなされ Baratal suite と呼ばれている (Buslov et al., 1993)。

ゴルニアルタイ山地北部の Baratal suite の石 灰岩からは，原生代末ベンド紀型のストロマトラ イトおよび microphytolite (植物性微化石) (Algotactis kabirsaensis Posp., Ambigolamellatus sp., Radiosus cf. sphaericus Z.Zhur., R. cf. badius Z.Zhur., Osagia sp., O. cf. tenuilamellata Reitl., Conophyton sp., Occultus sp., Jasenia sp.) が産 する。これらの化石の産出に基づき, Baratal suiteの石灰岩はベンド系を含むとされている (Zybin and Sergeev, 1978; Buslov et al., 1993)。

また, 北部地域 Edigan 川流域では, Baratal suite 相当の石灰岩に隣接する珪質頁岩から, カン ブリア紀初期の海綿の骨針化石 (Protospongia sp.）の産出が報告されている（Afonin, 1976）。 Buslov et al. (1993）は，これらの化石に基づき Baratal suite の石死岩の年代を, ベンド紀からカ ンブリア紀初期に及ぶとみなした。しかし，上述 のいずれの産出化石も詳しい年代決定には不十分 であり，とくに，カンブリア紀の年代を明確に示 す化石が石灰岩中から産していない。したがって， 現状では Baratal suiteの石灰岩の生層序および 年代は，まだほとんど明らかにされていないと いってよい。

以下に，筆者らの調査で初めて詳細が明らかに なったクライ地域およびアッカヤ地域の石灰岩の 層序・岩相および産状について，個別に記載する。 
なお本稿では, 両地域とも模式地からは離れてい るものの, 産状・岩相が類似することから, クラ イおよびアッカヤ両地域の緑色岩類および石兏岩 を一括して, Manzherok 緑色岩および Baratal 石灰岩と呼ぶことにする。

\section{IV. クライ地域の Baratal 石灰岩}

\section{1）クライ地域の地質概要}

クライ地域は, ゴルニアルタイ山地の南東部の Altay 共和国 Kosh-Agach 地区 Kurai 集落から西 へ約 $5 \mathrm{~km}$ 付近に位置する（図 2)。本地域には, カンブリア紀付加体の緑色岩および石灰岩が，お よそ $10 \mathrm{~km}$ 四方にわたり広く分布する。この地域 のカンブリア紀付加体は, 主に緑色岩から構成さ れ, 従来 Manzherok suite と呼ばれたものにあた る。付加体は, 東側において低温高圧型変成岩と, また西側では非変成カンブリア系砂岩・泥岩層と 北西一南東方向の高角度断層で接する。

この地域は起伏差が小さく, 草地と林が広く覆 うために，付加体構成岩の中で比較的風化に弱い 緑色岩は露出面積が限られる。一方, 石灰岩は比 較的よく露出している。筆者らの野外調査の結果 から，これまで報告されていた約 $1,800 \mathrm{~m}$ に及ぶ 石灰岩の厚さは，抒そらく構造的にくり返して累 重した複数の石灰岩岩体の見かけの積算層厚にあ たり, 初生的な層厚は $200 \sim 300 \mathrm{~m}$ 程度と推定さ れる。

クライ地域のカンブリア紀付加体は, 主に緑色 岩類からなり, 東西約 $8 \mathrm{~km}$, 南北約 $5 \mathrm{~km}$ の範囲 に広く分布する（図 3)。この地域の付加体は，ほ ぼ水平な断層によって区分される 2 つの地質体か らなる。下盤の付加体は主に火山砕屑岩起源の緑 色岩からなり,それらはほぼ $\mathrm{N} 20^{\circ} \mathrm{E}$ の走向を有す るが，傾斜は大きく変化し，20-90。で東あるいは 西に傾斜する。見かけの層厚は $200 \mathrm{~m}$ 以上である。 一方, 上盤の付加体は塊状の緑色岩および Baratal 石灰岩からなる。この地質体は, 地表浸 食によって分布が孤立化し，それぞれが $1 \mathrm{~km} \times$ $0.5 \mathrm{~km}$ 程度の面積に露出する巨大なクリッペと して産する（図 3)。緑色岩は, 塊状の玄武岩溶岩 を原岩とする。石灰岩は一般に灰白色で，層理が
不明瞭な塊状石灰岩が多い。ただし一部は層理を 持ち, また石灰岩角磁岩からなる。さらに, ドロ マイト質, あるいは珪質な部分，および黑色有機 質な部分を含む。これらのいずれのタイプの石灰 岩も，陸源の粗粒砕屑物を全く含まない。

緑色岩の層厚は, Chuya 道路から南方数 $100 \mathrm{~m}$ 付近に露出するクリッペ内では, 約 $100 \mathrm{~m}$ 程度で ある。一方, 石灰岩の層厚は約 $20 \mathrm{~m}$ 程度しかな く, しかもブロック毎に, $\mathrm{N} 10^{\circ} \mathrm{E}-\mathrm{N} 81^{\circ} \mathrm{E}$ の様々 な走向を示し，傾斜も $22^{\circ} \mathrm{W}-80^{\circ} \mathrm{E}$ と様々である。 本研究では, 石灰岩の起源を探る目的で, 上盤 の地質体について詳しく調査した。以下の記載は いずれも上盤の地質体に関するものである。

\section{2) Baratal 石灰岩の層序}

露出状況が必ずしも良好ではないクライ地域に おいて $(3 \mathrm{~km} \times 5 \mathrm{~km}$ : 図 3), 詳しい野外調査を 行なった結果，KR-1，KR-2，および KR-3の 3 つのセクションにおいて, Manzherok 緑色岩の 上に Baratal 石灰岩が累重する状況が観察できた。 以下では緑色岩と石灰岩の累重関係に焦点をあて て，これらの3つのセクションの層序について記 載する。

1. KR-1 セクション

クライ地域中央部のやや西側に位置する KR-1 セクション(口絵 5-写真 1) において, Manzherok 緑色岩と Baratal 石灰岩との初生的層序が最もよ く観察される。図 4 に 1/100のスケールで作成し た本セクションの露頭スケッチを，また図 5 に柱 状図を示す。緑色岩と石灰岩は, 南北約 $250 \mathrm{~m}$, 東西約 $60 \mathrm{~m}$ の幅で露出する。玄武岩質緑色岩は 厚さ約 $20 \mathrm{~m}$ の塊状溶岩からなり, その上位に層 厚 $12 \mathrm{~m}$ 以上の灰色塊状石灰岩が重なる。

緑色岩とその上位の石灰岩との境界は, 走向方 向に約 $150 \mathrm{~m}$ にわたってほぼ連続的に追跡される （図 4)。露頭の南端（KR-1-a：図 4）で, 緑色岩 の直上に石灰岩が堆積した関係が最も明瞭に観察 される。この部分における緑色岩類と石灰岩との 接触面はほぼ平坦で, $\mathrm{N} 20^{\circ} \mathrm{E}, 40^{\circ} \mathrm{S}$ の走向・傾 斜を持ち, 上位の石灰岩の層理面とほぼ平行である。

また，一部では塊状の緑色岩の上面が凹凸を持 ち，その凹部を埋めて石灰岩が堆積した様子が観 


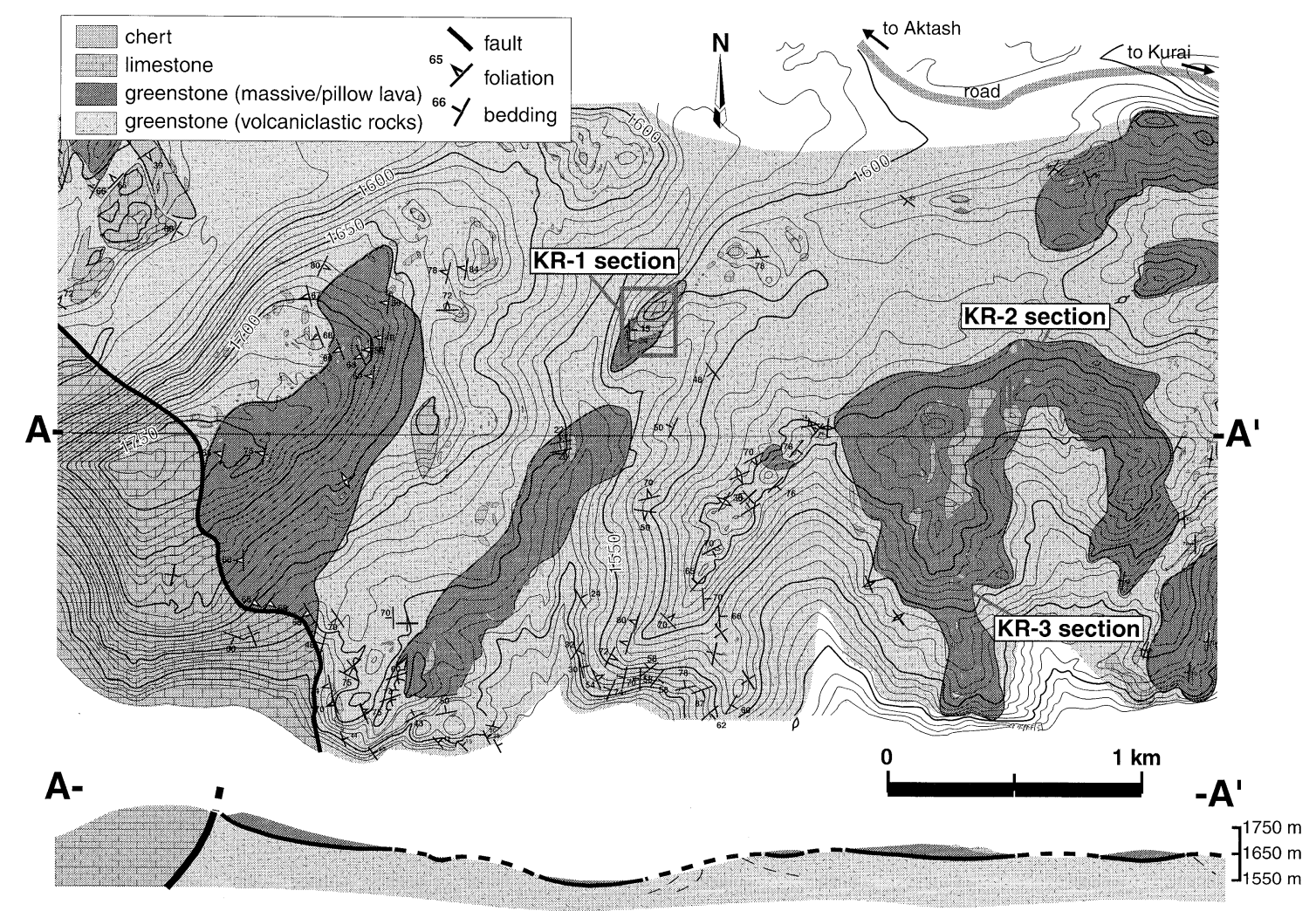

図 3 Kurai 地域の岩相分布図㧍よび地質断面図.（太田・宇都宮・石川・内尾・北島および Buslovによる 1997 年，1998 年および 1999 年の野外調査に基づく)

Fig. 3 Lithologic map and cross section of the Kurai area. (Based on the survey by Ota, Utsunomiya, Ishikawa, Uchio, Kitajima, and Buslov in 1997, 1998, and 1999)

察される（口絵 5 -写真 2 )。また塊状の緑色岩（溶 岩）とその上位の石灰岩の間に，厚さ約 $30 \mathrm{~cm} の$ 玄武岩質火山砕屑岩を起源とする緑色岩がレンズ 状に狭在される部分もある。

緑色岩：主に玄武岩質および一部ドレライト質 な塊状溶岩を原岩とする。玄武岩質部分は明暸な 枕状構造を持たない。ただし，一部に明暸な急冷 縁や発泡などの組織が認められ，水中で噴出した シート状溶岩の断片とみなされる。鏡下では主に 玄武岩質組織が観察され，まれにオフィティック 組織が観察される。自形短冊状の斜長石の斑晶が 散在し，石基には斜長石と単斜輝石が認められる。 斜長石の多くは，アルバイト化している。

石灰岩：主に灰色塊状石灰岩からなる（図 5)。 緑色岩と接する最下部の約 $30 \mathrm{~cm}$ は, 暗灰色塊状
石灰岩からなり, その上位に層厚約 $12 \mathrm{~m}$ の灰色 塊状石灰岩が重なる。

灰色塊状石灰岩は主に石灰泥からなり, Dunham（1962）による lime mudstone に分類され る。灰色塊状石灰岩は, 部分的に層厚約 $20 \mathrm{~cm}$ の 暗灰色石灰岩の薄層や, 暗灰色チャートノジュー ルを含む。暗灰色塊状石灰岩も, 同様に lime mudstone に分類され, 炭質物を比較的多く（体 積比で約 $0.5 \%$ ）含む。炭質物は, 長径約 $3 \sim 10$ $\mu \mathrm{m}$ の不定形で，カルサイト粒子の間に産する。 暗灰色チャートノジュールは, 層理面に沿って長 さ $20 \sim 40 \mathrm{~cm}$, 厚さ $1 \sim 2 \mathrm{~cm}$ 程度のレンズとし て産し, 明瞭な内部構造を持たない。これらの石 灰岩は，いずれも陸源粗粒砕屑物を全く含まない。 灰色塊状石灰岩の一部にはドーム状のストロマ 

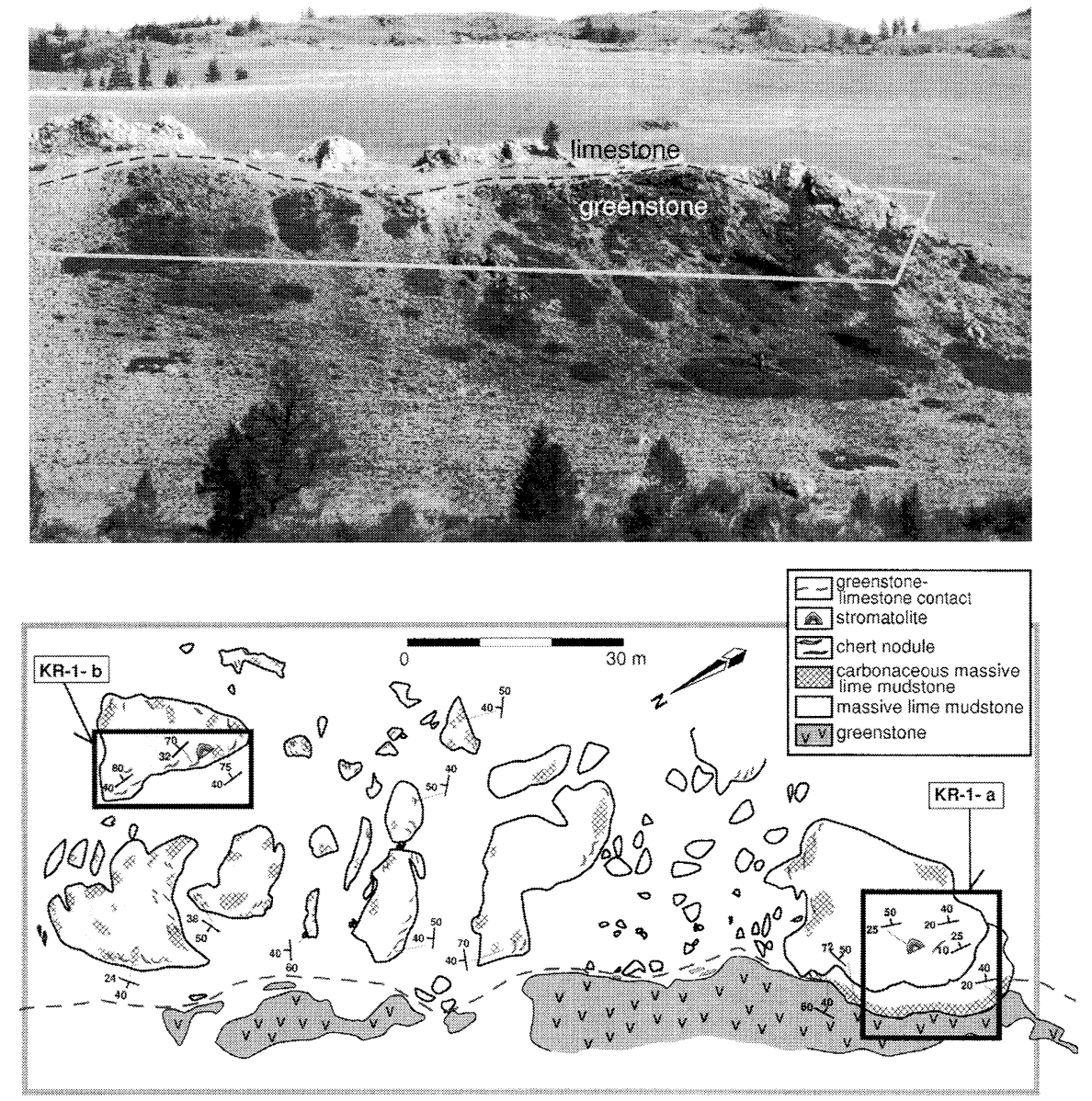

図 4 Kurai 地域 KR-1 セクション周辺の石灰岩および緑色岩の産状.

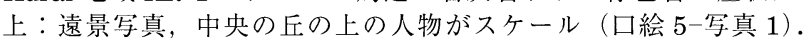

下：上図の白枠部分の平面スケッチ.

KR-1 セクションの位置は図 3 参照.

Fig. 4 Distant view and sketch of limestone and greenstone in the KR-1 section. Upper photo : Photograph showing distant view of the outcrop in the KR-1 section. Lower photo: sketch of the white frame part shown in the upper photo.

トライト構造が認められる（口絵 5 -写真 6 左 ; 図 5)。KR-1-a セクションにおいては, 石灰岩基底か ら約 $7 \mathrm{~m}$ 上位の層準に, また KR-1-b セクション においては, 石灰岩の最下位から約 $3 \mathrm{~m}$ 上位に産 する。そのドーム状構造は, 直径約 $40 \mathrm{~cm}$, 高さ 約 $40 \mathrm{~cm}$ のサイズで，層序学的上位に向かって成 長した状態を呈する（口絵 5-写真 6)。内部は約 1 〜 $2 \mathrm{~mm}$ 厚の細かな層からなり, 顕微鏡下での組
織の観察では, カルサイトの層と炭質物を含むカ ルサイトの層がラミナを形成する様子が確認され る（口絵 5 -写真 6 右）。またこの層構造はドーム 構造とほほ平行に発達する（口絵 5 -写真 6 左）。

\section{KR-2 セクション}

クライ地域東部に位置する KR-2 セクション(図 3）は, 約 $1.3 \mathrm{~m}$ 厚の緑色岩とその上位に累重する 約 $12 \mathrm{~m}$ 厚の Baratal 石灰岩からなる。図 6 に露 

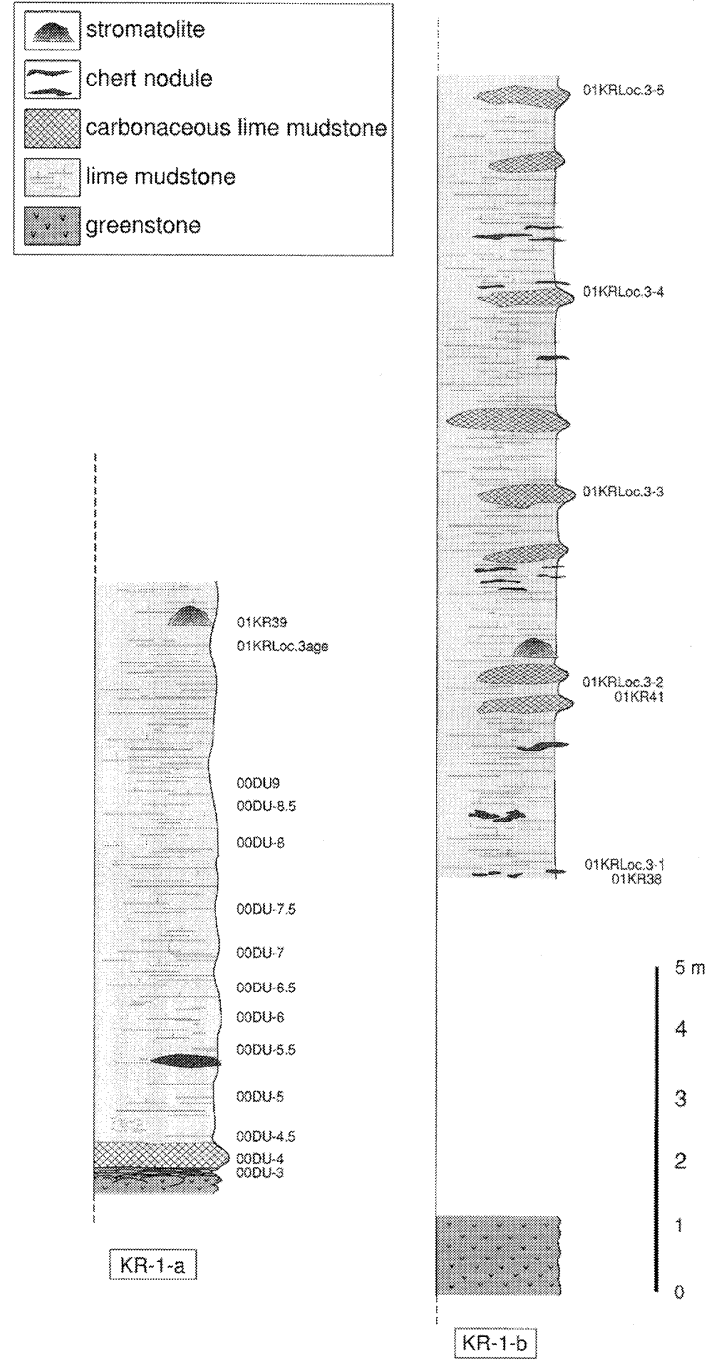

図 5 Kurai 地域の KR-1 セクション (KR-1-a およ び KR-1-b）の柱状図。位置は図 4 を参照. 玄武岩質緑色岩上に，灰色塊状石灰岩が累重 する。

柱状図右の記号は, サンプル番号.

Fig. 5 Stratigraphic columns of the KR-1 section. See Fig. 4 for the localities of the KR-1-a and the KR-1-b. Light gray massive limestone conformably rests on the basaltic greenstone.

Numbers on the right side of the stratigraphic columns indicate the sample horizons.
頭のスケッチを, また柱状図を図 7 に示す。緑色 岩と Baratal 石灰岩は, 南北約 $15 \mathrm{~m}$, 東西約 $5 \mathrm{~m}$ の幅で露出する。緑色岩は二分され, 下半は厚さ 約 $70 \mathrm{~cm}$ の立武岩質塊状溶岩起源の緑色岩から, また上半は厚さ約 $60 \mathrm{~cm}$ の同質火山砕屑岩を起源 とする緑色岩から構成される。それらの上位の Baratal 石灰岩は, 層状石灰岩および石灰岩礫岩 からなる。図 7 の柱状図に示すように, 緑色岩類 との境界の直上から, 層厚約 $1.2 \mathrm{~m}$ の石灰岩碩岩, 層厚約 $0.3 \mathrm{~m}$ の層状石灰岩, 層厚約 $2.5 \mathrm{~m}$ の石灰 岩礫岩, 層厚約 $4 \mathrm{~m}$ の層状石灰岩, 層厚約 $2 \mathrm{~m}$ の 石疢岩礫岩, 層厚約 $0.4 \mathrm{~m}$ の層状石灰岩, 層厚約 $1.5 \mathrm{~m}$ の石灰岩碟岩層, そして層厚約 $1 \mathrm{~m}$ の塊状暗 灰色石灰岩が順次整合に重なる。その上位には, 断層を挟んで層状石灰岩が層厚約 $14 \mathrm{~m}$ 重なる。

緑色岩と石灰岩碩岩との接触面は, 層状石灰岩 の層理とほぼ平行である。その境界面は数 $10 \mathrm{~cm}$ オーダーの 凹凸を持つが, 石灰岩礫岩は, 滑り面 などを介さず緑色岩の上位に直接重なる。

緑色岩：玄武岩質塊状溶岩を原岩とする下部と 火山砕居岩起源の上部に分けられる。玄武岩質塊 状溶岩を原岩とする下部は, 一部に明瞭な枕状構 造を持つ。また, 急冷縁や発泡などを持つことから， KR-1 セクションの塊状緑色岩と同様に, このセ クションの緑色岩も水中で噴出したものと推定さ れる。鏡下では, 斜長石および単斜輝石からなる 石基の中に, 自形短冊状の斜長石が散在する。才 フィティック組織が認められることもある。斜長 石は，すべてアルバイト化している。上部の火山 砕屑岩起源の緑色岩は, 主に泥サイズの粒子から なり，部分的に砂サイズの岩片を含む。いずれも 塊状緑色岩の岩片のみからなる。基質は主に直径 $30 \sim 40 \mu \mathrm{m}$ 以下の細粒な単斜輝石と斜長石から なり, その他, 二次的な変成・変質鉱物として緑 泥石などの有色鉱物や磁鉄鉱などの不透明鉱物を 伴う。

層状石灰岩：灰色部と褐色を带びた灰色部との 互層からなる。主に灰色部の中に, 厚さ約 $3 \sim 4$ $\mathrm{cm}$ の褐色を帯びた灰色部の層を多数挟む（図 8 (a)）。灰色部および褐色を帯びた灰色部ともに, Dunham（1962）による lime mudstone に分類 


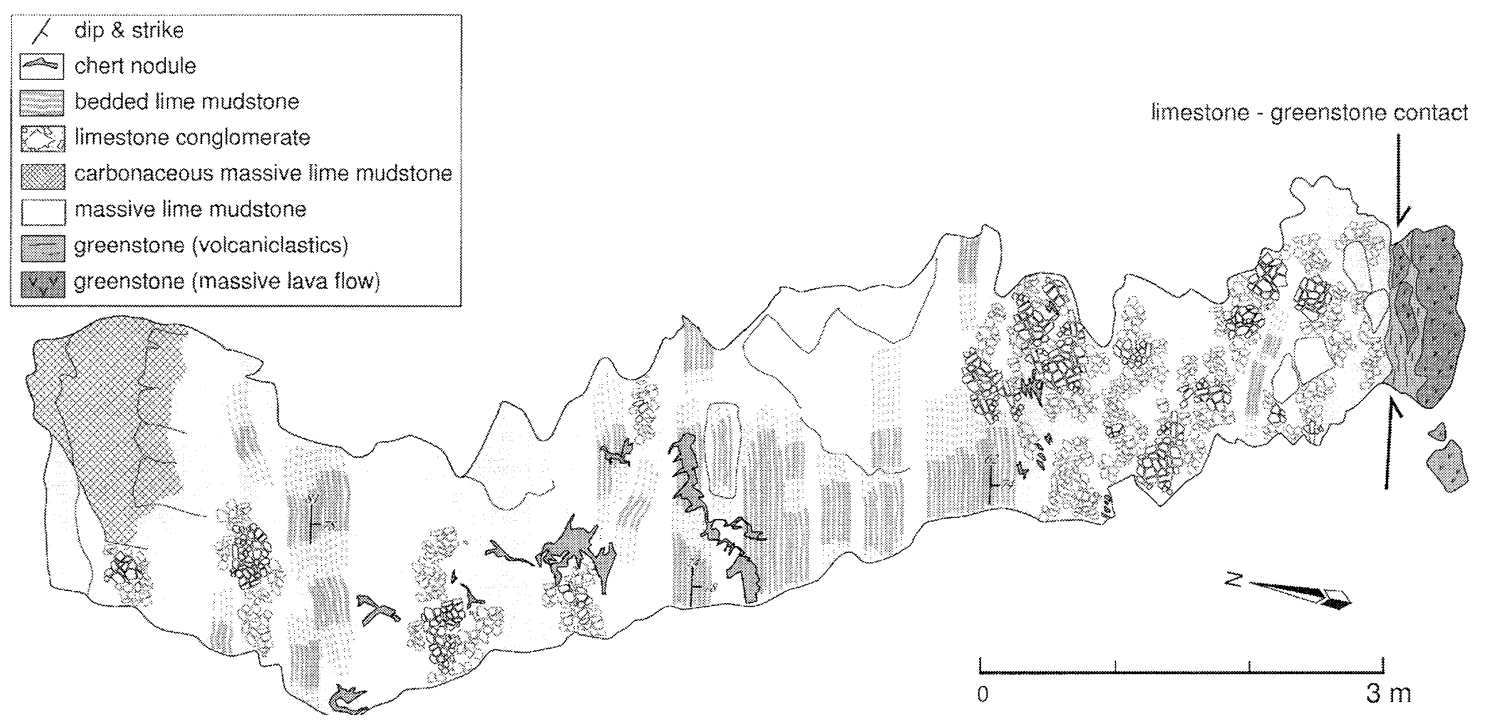

図 6 Kurai 地域の KR-2 セクションの石灰岩および緑色岩の産状スケッチ.

Fig. 6 Sketch of contact between limestone and greenstone at the KR-2 section in the Kurai area.

される。

少なくとも 3 層準に, 褶曲が認められる（図 8 (b))。約 $50 \mathrm{~cm}$ の特定層準の薄い層状石灰岩が Z 字状に褶曲する。それらの層は, しばしば側方連 続せず，分断されていることが多い。一方，その 層の上下の地層は, 褶曲していない。

石灰岩碩岩: 長径が数 $\mathrm{cm}$ 程度から $20 \mathrm{~cm}$ 程度 の石灰岩の亜角䃏を主体とする（図 8 (c) )。礫の 分級は悪い。石灰岩磼はいずれも lime mudstone からなる。砂岩の基質も細粒の石灰泥から構成さ れている。切断面における砂および基質の面積比 から， $2 \%$ 程度のチャートや緑色岩の礫を含むと 見積もられる。砂と基質との量比は約 $4: 1$ であり, 礫支持の構造を持つ。

塊状暗灰色石灰岩: 炭質物に富む lime mudstone からなる。炭質物は, 直径 $20 \sim 30 \mu \mathrm{m}$ の 微小方解石結晶の間に分布し, 長径 $3 \sim 10 \mu \mathrm{m}$ 程 度の不定形である。また，炭質物の含有率は，体 積比で約 $0.5 \%$ あるる。

これらの石灰岩はいずれも，石英・長石質の陸 源粗粒砕首物を全く含まない。これらすべての石 灰岩中に, 厚さ数 $\mathrm{cm} \sim$ 数 $10 \mathrm{~cm}$ の不定形の暗灰
色チャートのノジュールが挟まれる。このチャー トノジュールは, 不定形ながら層理面に沿って産 し, 初生的な内部構造は認められない。

3. KR-3 セクション

クライ地域の東側やや南部に位置する KR-3 クション（図 3）は，層厚約 $11 \mathrm{~m}$ の緑色岩と 1.5 $\mathrm{m}$ 厚の塊状灰色石灰岩からなる。緑色岩と石灰岩 は, 南北約 $5 \mathrm{~m}$, 東西約 $12 \mathrm{~m}$ の幅で露出する。緑 色岩は, 厚さ約 $10 \mathrm{~m}$ の枕状溶岩およびその上位 に重なる厚さ約 $90 \mathrm{~cm}$ の火山砕屑岩起源の緑色岩 である。緑色岩の枕状構造の垂れ下がりは系統的 に北上位を示し, 緑色岩の上位に石灰岩が堆積し たことを示す。枕状立武岩質緑色岩の上位に，火 山砕屑岩起源の緑色岩を挟み, 石灰岩が重なる。 また，石灰岩と緑色岩の間には滑り面などは認め られない(口絵 5-写真 3)。石灰岩は層厚約 $1.5 \mathrm{~m}$ の灰色の塊状石灰岩からなり, その上位は露出し ていない。石灰岩の層理面は, 石灰岩と緑色岩と の境界面とほぼ平行である。

緑色岩：主に玄武岩質塊状溶岩を原岩とし，一 部に長径約 $25 \mathrm{~cm}$ 程度の明暸な枕状構造を持つ (口絵 5-写真 3 )。明瞭な急冷縁や発泡などの組織 


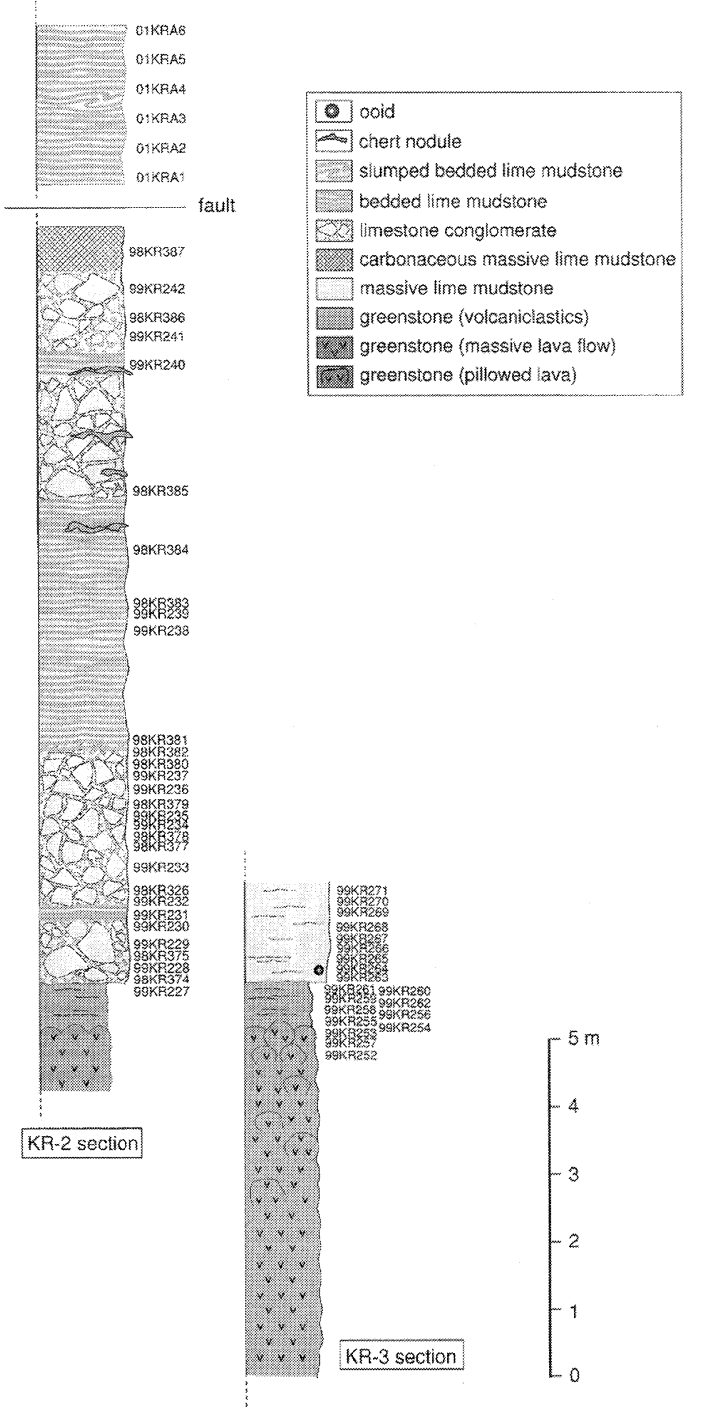

図 7 Kurai 地域の KR-2 および KR-3 セクション の柱状図.

石灰岩角碩岩が玄武岩質緑色岩（枕状溶岩） 上に累重する。

柱状図右の記号はサンプル番号を示す。

Fig. 7 Columnar sections of limestone at KR-2, KR-3 sections in the Kurai area.

Limestone overlies the greenstone.

Numbers on the right of the columns indicate the sample horizons.
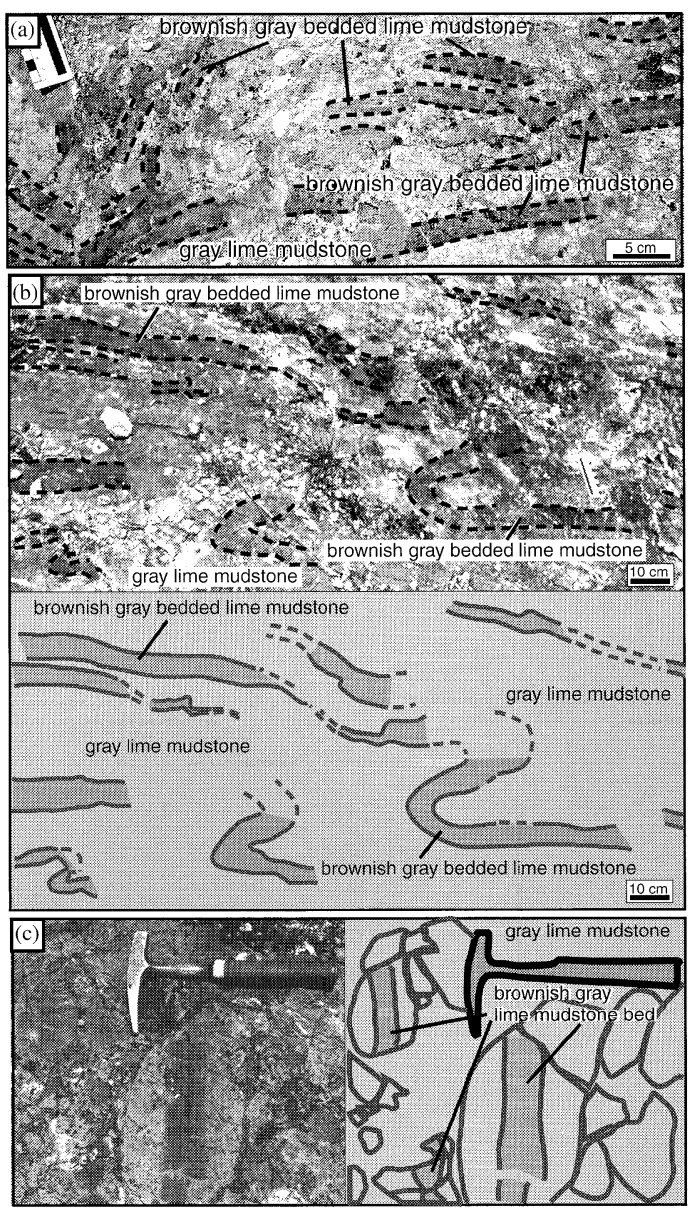

図 8 KR-2 セクションで観察される層状石灰岩と その中のスランプ構造および带角磕.

（a）褐色を帯びた灰色の lime mudstone が層をな す様子。

（b）褐色を帯びた lime mudstone の層がなすスラ ンプ構造とそのスケッチ. Plasticに Z 型に 折り鲳まれた褶曲構造が観察される。

(c) KR-2 セクションの亜角磁とそのスケッチ.

Fig. 8 Bedded lime mudstone and their slumping structures at the KR-2 section.

(a) Outcrop photograph of brownish gray bedded lime mudstone.

(b) Outcrop photograph and sketch of brownish gray lime mudstone with slump structures, plastically folding $\mathrm{Z}$ shape.

(c) Outcrop photograph and sketch of limestone conglomerate. 
が認められ，原岩は水中で噴出したと推定される。 塊状溶岩起源の緑色岩は大半が玄武岩質組織を持 つが，オフィティック構造を持つこともある。斑 晶および石基は共に単斜輝石と斜長石からなる。 この緑色岩の鏡下の特徴は, とくに KR-1 セク ションの塊状緑色岩に類似する。また, 上位の火 山砕屑岩起源の緑色岩は, 塊状緑色岩の砂サイズ の岩片を含み, 主に直径約 $30 \sim 40 \mu \mathrm{m}$ 以下の細 粒な単斜輝石と斜長石からなる。その他に二次的 な変成・変質鉱物として, 緑泥石などの有色鉱物 や磁鉄鉱などの不透明鉱物を伴う。

石灰岩: 灰色塊状石灰岩は不明瞭な層理を持つ。 単層の厚さは約 $8 \mathrm{~cm}$ である。Dunham（1962） による lime mudstoneに分類される。直径約 0.5 $\mathrm{mm}$ のオーイドを含む層準があり，多い部分では， オーイドが体積比で, 最大約 $5 \%$ を占める。オー イド粒子は明瞭な同心円構造を持つものが多い。 また，オーイド粒子の破片が，石灰泥基質中に多 数産する例も確認される。また，この石灰岩は陸 源性粗粒砕屑物を全く含まない。

\section{V. アッカヤ地域の Baratal 石灰岩}

\section{1）アッカヤ地域の地質概要}

アッカヤ地域は, ゴルニアルタイ山地の南東部 の Altay 共和国 Kosh-Agach 地区 Chagan-Uzun 集落より西へ約 $15 \mathrm{~km}$ の付近の Akkaya 川流域に あって, Kurai 集落と, Chagan-Uzun 集落のほ ぼ中間に位置する（図 2)。本地域には，カンブリ ア紀弱变成付加体の緑色岩類および石灰岩が広く 分布する。本地域は起伏に富み, また植生も少な いため, 各種岩石は良好に露出している（図 9, 図 10)。付加体は，北側に分布する低温高圧型の 変成岩体, 北東側に分布するデボン紀の火山岩類, および西側に非変成カンブリア系の砂岩・泥岩に 挟まれて分布し，これらの地質体とはいずれも高 角度断層の関係で境される（図 2)。

本地域の弱変成付加体は, ほとんど緑色岩類と 石灰岩のみから構成され, その他の砕屑岩類をほ とんど含まない。これら両者は各々，上述のクラ イ地域の Manzherok 緑色岩類および Baratal 石 灰岩と類似した岩相を持つことから，本稿ではこ
の地域の緑色岩抢よび石灰岩についても同様の名 称を用いる。

本地域の付加体は, ほぼ水平な断層を介して構 造的に大きく二分され, 下盤は緑色岩から, そし て上盤は緑色岩および石灰岩からなる。上盤は, 地表での削剥によって地形的高所に孤立したク リッペとして産する（図 9）。

下盤の緑色岩類は, Chuya 道路の南側に北西一 南東方向にのびた長径約 $15 \mathrm{~km}$ のレンズ状の分布 を持つ（図 2)。主に火山砕屑岩起源の緑色岩から なり，それらは抢よそ $\mathrm{N} 10^{\circ} \mathrm{W}$ の走向を有するが， 傾斜は大きく変化し $25-80^{\circ}$ で東または西に傾斜 する。緑色岩のみかけ上の層厚は $300 \mathrm{~m}$ 以上であ る。

上盤の玄武岩質緑色岩および石灰岩はクリッペ として産し, 各々約 $500 \mathrm{~m} \times 600 \mathrm{~m}$ の面積の分布 を持つ(図9)。緑色岩の枕状構造の垂れ下がりは, 緑色岩と石灰岩の層位関係の上下が逆転していな いことを示す。

クリッペの一部として産する Baratal 石灰岩は, 塊状あるいは枕状溶岩起源の緑色岩の上位に重な り, 層厚は最大で約 $50 \mathrm{~m}$ である(図 10)。本地域 の Baratal 石灰岩は, 実際には石灰岩角砂岩を主 体とし，一部に灰色層状石灰岩と炭質物を含む暗 灰色層状石灰岩の細かな交互層および不明瞭な層 理面を持つ。灰色塊状石灰岩を含む。どの夕イプ の石灰岩も，陸源の粗粒砕屑物を全く含まない。 以下にアッカヤ地域の Baratal 石灰岩の詳しい層 序について記載する。

\section{2) Baratal 石灰岩の層序}

本地域の Baratal 石灰岩は, 長径が 500 ～ 600 $\mathrm{m}$, 厚さ約 $30 \mathrm{~m}$ の巨大なレンズ状ないしブロック 状岩体として産する（図 9）。本地域で直接野外観 察した露頭の数は約 20 個所であるが，そのうち， 露頭状況が良好な AK-1, AK-2, および AK-3の 3 セクションで, 石灰岩初生層序を確認することが できた（図 9)。とくにAK-1 セクションにおいて は, Baratal 石灰岩と基盤の緑色岩が接触する様 子が良好に観察され，また AK-2 および AK-3セ クションでは, 石死岩砂岩や層状石灰岩などの異 なる 4 種類の岩相および層序が観察された。 

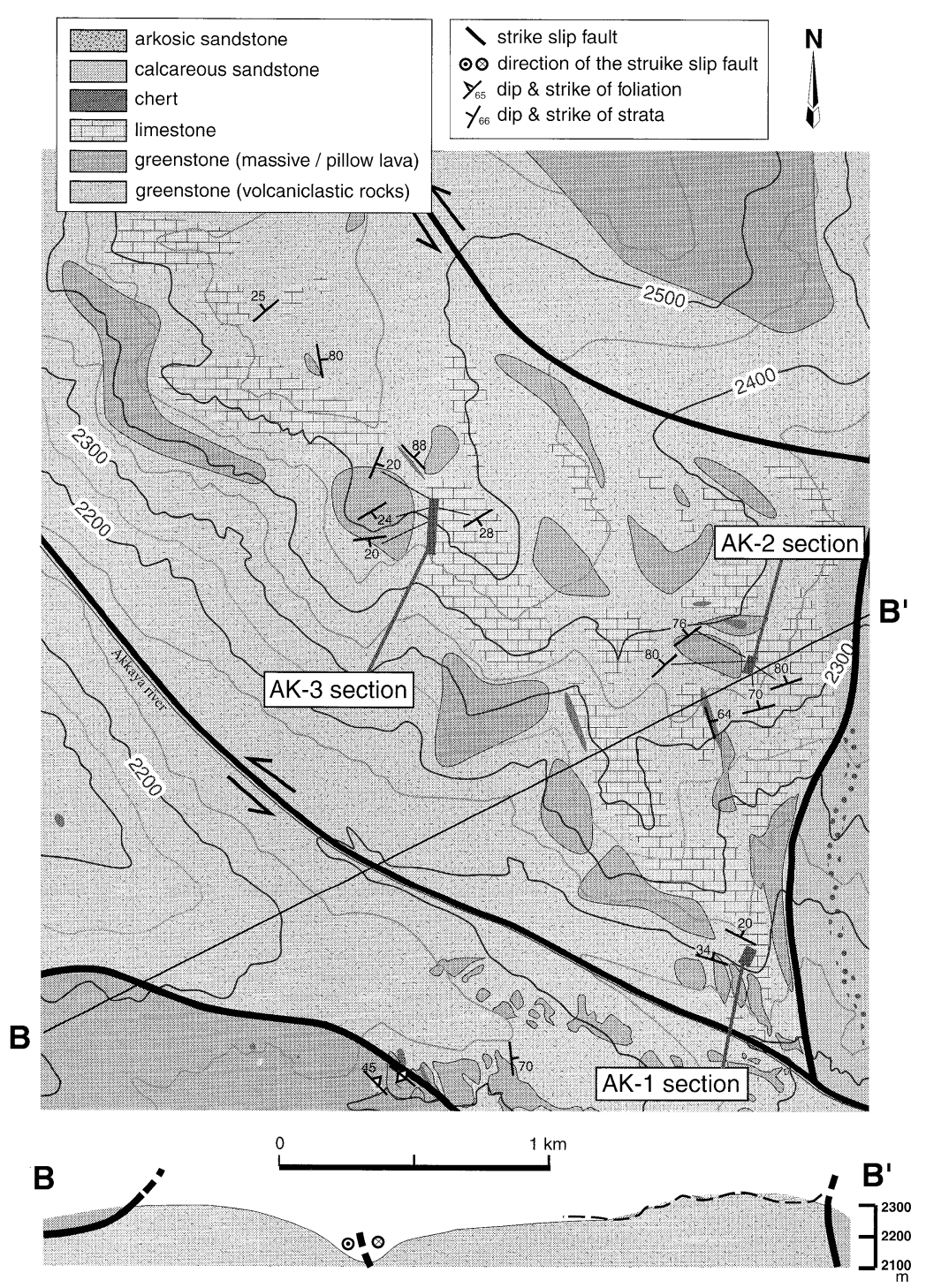

図 9 Akkaya 地域の岩相分布 図打よび地質断面図。（太 田・宇都宮・内尾・石川・ 北島・磯㟝扔よび Buslov による 1999 年および 2001 年の野外調査に基づく)

Fig. 9 Lithologic map of the Akkaya area. (Based on the survey by Ota, Utsunomiya, Uchio, Ishikawa, Kitajima, Isozaki, and Buslov in 1999 and 2001)
以下に, AK-1, AK-2 および AK-3 セクション の Baratal 石灰岩の層序について記載する。

1. $\mathrm{AK}-1$ セクション

アッカヤ地域のやや南東に位置し, Akkaya川 の北岸側の尾根に露出する。この周辺の地表には 植生がほとんどなく, 緑色岩とその上位に重なる 石灰岩啋岩が南北約 $250 \mathrm{~m}$, 東西約 $100 \mathrm{~m}$ の幅で 広く露出する（図 9)。緑色岩は主に厚さ約 $30 \mathrm{~m}$ の塊状溶岩からなり, 最上部に厚さ約 $20 \mathrm{~cm}$ の火 山砕屑岩を伴う。その上位に, 層厚約 $40 \mathrm{~m}$ の石
灰岩角礫岩層が重なる。

緑色岩とその上位の石灰岩との境界は, 走向方 向に約 $100 \mathrm{~m}$ にわたってほほ連続的に観察される （図 10）。玄武岩質塊状溶岩を原岩とする緑色岩の 上面の凹凸を埋めるように, 火山砕屑岩起源の緑 色岩が累重し，さらにその上位に石灰岩角礫岩が 整合に重なる。また, 緑色岩と石灰岩碟岩との接 触面の走向・傾斜はおよそ $\mathrm{N} 80^{\circ} \mathrm{W}, 34^{\circ} \mathrm{N}$ であり, 石灰岩礫岩が持つ層理面の走向・傾斜とほぼ平行 である。 


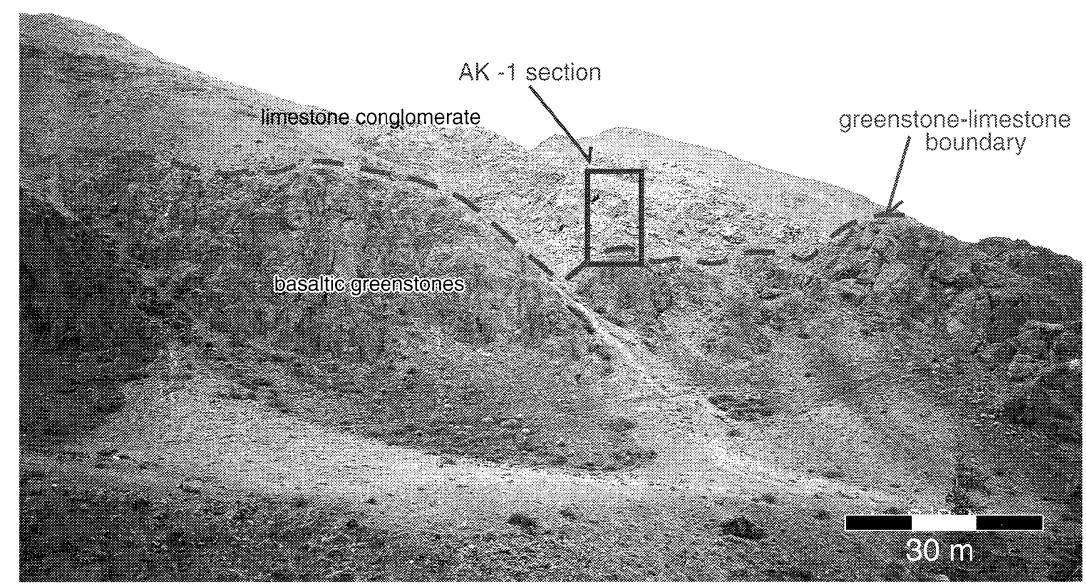

図 10 Akkaya 地域の AK-1 セクション周辺で観察される緑色岩とその上位に重な る石灰岩砂岩.

Fig. 10 The outcrop around the AK-1 section in the Akkaya area.

緑色岩：主に玄武岩および一部はドレライトを 原岩とする。玄武岩質の部分には, 明暸な枕状構 造は認められない。ただし, 一部には明瞭な急冷 縁や発泡などが認められ, 水中で噴出したシート 状溶岩が原岩に含まれるとみなされる。鏡下では, 塊状溶岩起源の緑色岩はオフィティック構造をも ち, 斑晶および石基は共に単斜輝石と斜長石から なる。また, 火山砕屑岩起源の緑色岩は, 主に泥 サイズの火山砕屑粒子からなる。それらの粒子は 約 $30 \sim 40 \mu \mathrm{m}$ 以下の細粒な単斜輝石と斜長石か らなり, その他, 二次的な少量の緑泥石などの有 色鉱物や磁鉄鉱などの不透明鉱物を伴う。部分的 に砂サイズの岩片も含む。

石灰岩鿬岩: 主に灰色の石灰岩角碩岩からなり (図 11, 図 12 (a)), 一部は暗灰色を呈する。こ の石灰岩礫岩は不明暸な層理を持つ。図 11 の柱 状図に示すように, この石灰岩礫岩は緑色岩の直 上に累重する。石灰岩磁岩の最下部は, 厚さ約 40 $\mathrm{cm}$ の特徴的な暗灰色部からなり, その上位に厚さ 約 $40 \mathrm{~m}$ の灰色部が重なる。いずれも礫の分級は 覀く, 級化などの堆積構造は認められない。上位 に向かい, 礫のサイズが大きくなる傾向が認めら れる。これらの石灰岩礫岩の礫および基質中には, 陸源の粗粒砕屑物は全く含まれない。

最下部の暗灰色石灰岩碩岩（図 11 : サンプル番
号 $01 \mathrm{AKa} 0 \sim 01 \mathrm{AKa} 1 ）$ は，主に長径約 $2 \mathrm{~mm}$ の 石灰岩小角䃇からなり (約 $95 \%$ ), 碟支持の組織 を持つ。基質は石灰泥からなる。石灰岩角礫の中 には, 直径約 $150 \sim 500 \mu \mathrm{m}$ 程度の球状から楕円 体状のオーイドを最大で約 $50 \%$ 含むものがある (図 12 (a) 右)。また, 長径約 $10 \mu \mathrm{m}$ で不定形の

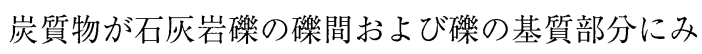
られる(体積比で約 $0.5 \%$ )。

灰色石灰岩角砂岩は, (図 11 : サンプル番号 01AKa2 〜 01AKa20), 礫は主に長径 $2 \sim 3 \mathrm{~mm}$ の角礫からなり，6〜12 $\mathrm{mm}$ の礫を約 $30 \%$ 含む。 （口絵 5-写真 4)。主に鿬支持であり，部分的に基 質支持の部分を伴う。基質は, 直径 $100 \sim 500 \mu \mathrm{m}$ のオーイドを多数含む石灰岩で, ooid packstone からなる(口絵 5-写真 5)。礫種は石灰岩, 玄武岩, およびチャートであり, 岩石研磨面における面積 比に基づくと, 各砂種の量比は石灰岩が約 $85 \%$, 玄武岩質緑色岩が約 10\%そして暗灰色チャート が約 $5 \%$ である。石灰岩角礫の多くは, 直径約 150 $\sim 500 \mu \mathrm{m}$ の球状から楕円体状のオーイドを最大 で約 50\%含む ooid packstone からなる。また， lime mudstoneを約 $5 \%$ 伴う。

2. AK-2 セクション

AK-2 セクションはアッカヤ地域の東部に位置 し(図 9), AK-1 セクションより約 $250 \mathrm{~m}$ 高い位 


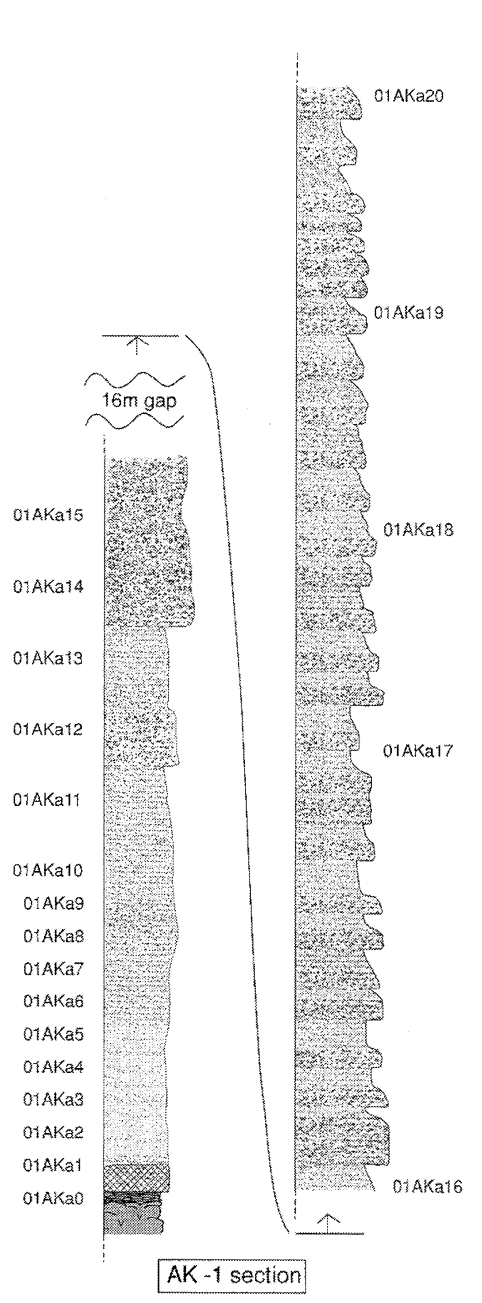

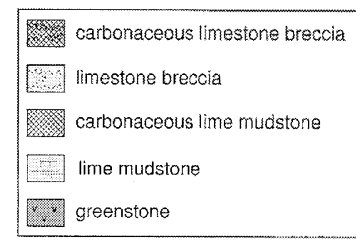

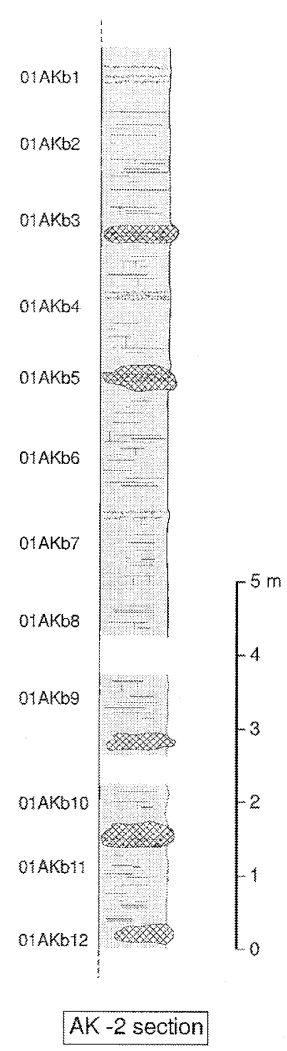

図 11 Akkaya 地域の AK-1 および-2 セクション の柱状図.

柱状図右の記号はサンプル番号を示す.

Fig. 11 Columnar sections of AK-1 and AK-2 sections in the Akkaya area. Numbers at the right of the columns indicate the sample horizons.
置に露出する。AK-1 セクションと同様, 周辺の地 表には植生がほとんどない。本セクションには, 石灰岩礫岩が南北約 $300 \mathrm{~m}$, 東西約 $200 \mathrm{~m}$ の幅で 広く露出する。

石灰岩磁岩:層厚約 $10 \mathrm{~m}$ の灰色石灰岩砂岩の中 に，暗灰色石灰岩の薄層を挟む（図 11）。灰色石 灰岩碩岩は，基質が体積比で約 95\%を占め, 少量 の径 2〜 4 mm の石灰岩および玄武岩質緑色岩の 角䃉を含む。基質支持の組織を持つ。基質は石灰 泥からなり, 基質中には球状から楕円体状で, 直 径 50 〜 $300 \mu \mathrm{m}$ のオーイドを約 $40 \%$ 含む。

暗灰色石灰岩の薄層は 20〜30 cm の厚さで, レンズ状に挟まれる。Dunham（1962）による lime mudstone に分類される。炭質物を体積比で 約 $0.3 \%$ 含む。この石灰岩礫岩中には, 基質および 砂中共に陸源性粗粒砕屑物を全く含まない。

3. AK-3 セクション

アッカヤ地域の中央部に位置し（図 9), 急勾配 の尾根に露出する。AK-1, および AK-2 セクショ ンと同様，周辺の地表には植生がほとんどない。 本セクションには, 石灰岩が南北約 $600 \mathrm{~m}$, 東西 約 $300 \mathrm{~m}$ の幅で広く露出する。

露頭の見かけ下位より, 下部層状石灰岩層（層 厚約 $6 \mathrm{~m}$ ), 暗灰色のチャートノジュールを含む塊 状石灰岩（層厚約 $5 \mathrm{~m}$ ), そして上部層状石灰岩 （層厚約 $10 \mathrm{~m}$ ）が露出する（図 13 ）。 

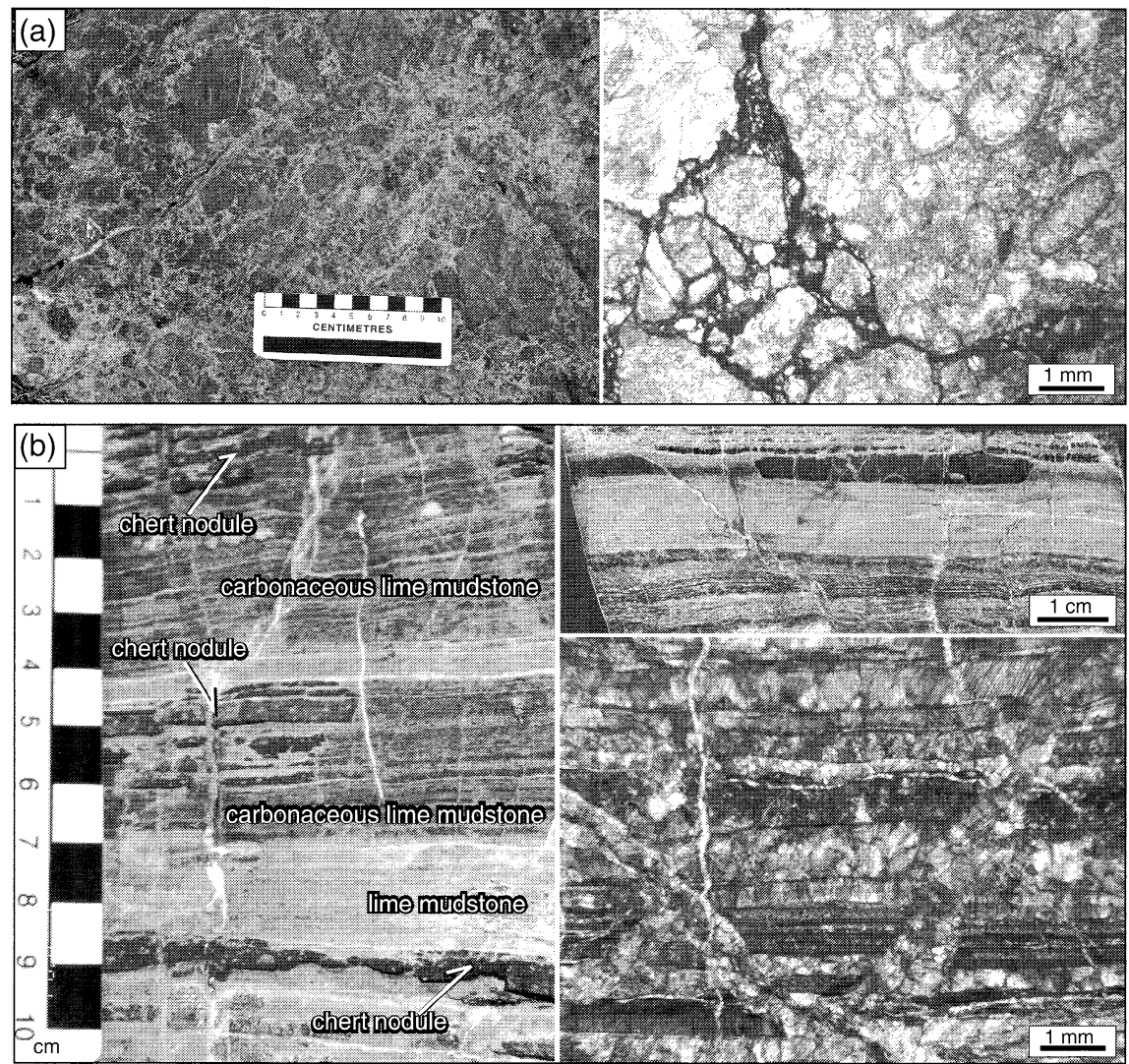

図 12 AK-1 および AK-3 セクションの石灰岩.

(a) AK-1 セクションの石灰岩角礫岩. 左：露頭表面写真. 右：AK-1 セクション（AKa 0) の石灰岩角砂岩薄片写真. 角唩中にオーイドが含まれる.

(b) AK-3 セクションの層状石灭岩 (AKc 2). 石灰泥からなる暗灰色石灭岩と灰色石灰岩が 互層する. 部分的にチャートノジュールが挟まれる. 左 : 露頭表面写真, 右上：研摩断 面写真. 右下：薄片写真.

Fig. 12 Limestone breccia in the AK-1 section and bedded limestone in the AK-3 sections.

(a) The left side : limestone breccia on the surface of the outcrop in the AK-1 section. The right side : A thin section of limestone breccia in the AK-1 section (AKa 0). Breccia includes ooids.

(b) Laminated limestone in the AK-3 section. Laminted light gray limestone and dark gray limestone are pailed. Chert nodules are being held in the limestone. Left photo : outcrop surface of laminated limestone. Upper right photo : cross section of laminated limestone. Lower right photo : A thin section of laminated limestone.

石灰岩：下部層状石灰岩は灰色で, 不明瞭な層 理面を持つ。Dunham（1962）による lime mudstone に分類される。中部の塊状石灰岩は，不明 瞭な層理面を持つ灰色の lime mudstone で, やゃ 珪質で硬く，暗灰色チャートノジュールを挟む。 ノジュールは層理面に沿って約 $1 \sim 8 \mathrm{~cm}$ 連続し,
やや細長いレンズ状の形をなすものが多いが，ま れに不定形のものが見られる。このチャートノ ジュール中には, 初生的な内部構造は認められな い。径 $2 \sim 4 \mathrm{~mm}$ の石灰岩やチャートの砂を含む 薄い層が挟まれる場合があり，不明瞭ながら級化 を示す。上部層状石灰岩は，灰色石灰岩の層㧍よ 


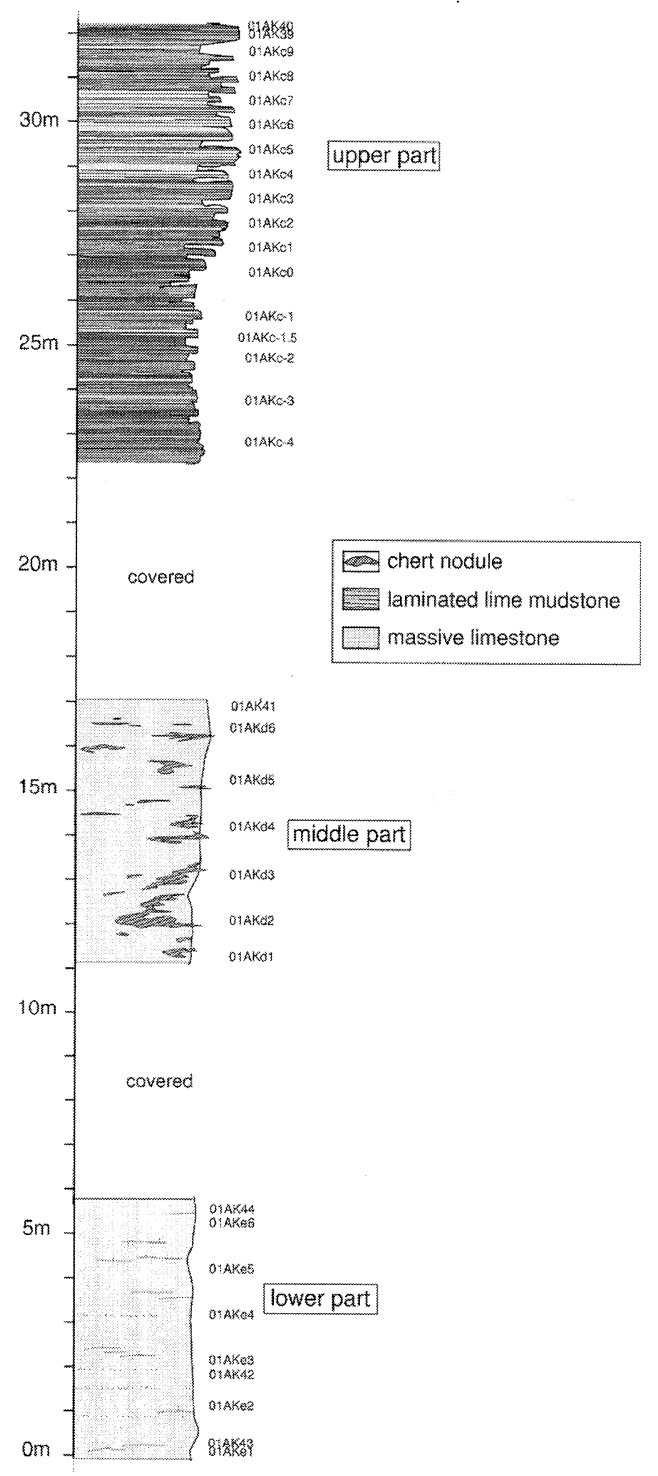

図 13 AK-3 セクションの柱状図.

柱状図右の記号はサンプル番号を示す。

Fig. 13 Columnar sections in the AK-3 section. Numbers on the right of the columns indicate sample horizons.

び暗灰色石灰岩の層が 1 〜 $\mathrm{cm}$ の交互層をなす (図 12 (b) 左)。単層中には, 厚さ約 $1 \sim 2 \mathrm{~mm}$ の細かな葉理が見られる（図 $12(\mathrm{~b})$, 右上および 右下)。灰色抒よび暗灰色石灰岩は, lime mudstone からなる。暗扊色の石灰岩部分は炭質物を含
む。炭質物は長径約 $5 \mu \mathrm{m}$ で, 不定形で, 石灰泥 をなすカルサイト粒子の間に分布する。含有率は 体積比で約 $0.3 \%$ であ。石灰岩のどの岩相にお いても，陸源性粗粒砕屑物を全く含まない。

\section{VI. 考 察}

本研究で明らかになったゴルニアルタイ山地の カンブリア紀付加体中の Baratal 石灰岩の層序と 岩相に基づき, 同石灰岩の初生的な堆積場と堆積 環境について考察する。まず, Baratal 石灰岩の 堆積基盤について考察し, 次に石灰岩自体の初生 的堆積場の復元を試みる。

\section{1）Baratal 石灰岩の堆積基盤}

Baratal 石灰岩の初生的堆積場を復元するにあ たって，まずその堆積基盤の起源およびテクト ニック・セッティングの特定が重要と考えられる。 上述のとおり, クライ地域の KR-1 および KR-3 セクションにおいては灰色塊状石灰岩 (lime mudstone）が，また KR-2 セクションにおいては 層状石灰岩および石灰岩碟岩が, 各々玄武岩質緑 色岩類の直上に堆積した様子が観察される。さら に, アッカヤ地域の AK-1 セクションにおいても, 石灰岩角砂岩が立武岩質緑色岩を直接覆つて堆積 した状況が観察される。いずれのセクションにお いても, 石灰岩と下位の緑色岩とは密着して接触 しており，両者の間に滑り面は認められない。し たがって，クライおよびアッカヤ地域の Baratal 石灰岩は, すべて初生的に玄武岩質緑色岩類を堆 積基盤として堆積したと判断される。

クライ地域㧍よびアッカヤ地域の玄武岩質緑色 岩類中には明瞭な枕状構造を持つものがあること から，その原岩の玄武岩は水中噴出した溶岩であ ると判断される。また，雨地域において玄武岩質 緑色岩類の層厚は火山砕屑岩起源の部分を含めて 約 $300 \mathrm{~m}$ に及ぶが，その中に石英・長石質の陸源 粗粒砕屑岩層を全く挟まない。したがって，この 厚い玄武岩岩体は, 陸源砕屑物の混入しない海域 で噴出したものと推定される。

Buslov et al. (1993) は，クライおよびアッカ ヤ地域の玄武岩質緑色岩類の化学組成を分析し, 原岩の玄武岩の一部がホットスポット型海洋島玄 
武岩に近い組成を持つことを報告した。さらに宇 都宮ほか（1998）は，クライ地域の緑色岩類が単 斜輝石の斑晶を多く含むことを見出し, 同緑色岩 が単斜輝石斑晶をほとんど持たない現世の中央海 嶺玄武岩とは明らかに異なった岩石学的特徵を持 つことを示した。ただし，これらの緑色岩類の希 土類元素組成は, 中央海嶺玄武岩のみならず シャッキー海膨やへス海膨のような巨大海台のそ れに類似する。以上のことから, 宁都宮ほか （1998）は，クライ地域の緑色岩類の原岩となっ た玄武岩の形成場として, ホットスポット型海山 よりも，より規模の大きな海台を想定すべきだと 結論した。これらのデータおよび考察に従えば, 今回検討した地域の玄武岩質緑色岩類は, もとも と大陸から離れた遠洋域に位置していた，過去の 海台あるいは巨大な海洋島の一部であった可能性 が高いと考えられる。したがって，クライおよび アッカヤ地域の Baratal 石灰岩は, 古海洋中央部 で形成された海台/海洋島の頂部の孤立型炭酸塩 プラットフォームとして堆積したと推定される。

\section{2) 古海台 / 海山頂部の浅海成石灰岩}

クライ地域の KR-1 および KR-3 セクションの Baratal 石灰岩は, 主に塊状の lime mudstone か らなり, 石灰岩砂岩を全く伴わない。一般に, 厚 い石灰泥は波浪等の影響の少ない生物礁の内側の ラグーンあるいは，それに類似した環境で堆積す ることが多く，バハマバンク等に現世の例が知ら れている (Halley et al., 1983)。したがって，ク ライ地域の lime mudstone は, 過去の海台/海山 頂部に発達した炭酸塩プラットフォームの中でも, ラグーンなどの低波浪エネルギーの穏やかな場で 堆積したと考えられる。

また KR-1 セクションの石灰岩の一部に, スト ロマトライト構造が確認された。ストロマトライ トはシアノバクテリアが形成するドーム状構造で あり，一般に潮間帯〜潮下帯において形成される (Reid et al., 1995; Seong-Joo et al., 2000; Riding, 2002 など)。KR-1 セクションのストロマト ライトは石灰質な層と炭質物に富んだ層との互層 によって構成されており, 現世のストロマトライ トの内部構造とよく一致する。KR-1 セクション
のストロマトライトは, シアノバクテリアによる 光合成が可能な浅海, とくに水深が $50 \mathrm{~m}$ 以浅の有 光帯の浅海底で形成されたと考えられる。

一方, クライ地域の KR-3セクションおよびその 周辺で観察される塊状の珪質石灰岩の一部には, 同心円構造を持つオーイドが多産する。オーイド およびオーライトは, 現世のペルシャ湾やグレー トソルトレークのような熱帯から亜熱帯の乾燥気 候域, 中でもとくに蒸発量の大きい地域の浅海に 産し, その生成環境は水深 $5 \mathrm{~m}$ 以浅の水の動きが 活発な場あるいはそれに隣接した場に限られる (Halley et al., 1983; Major et al., 1996; Reither et al., 1997 など)。KR-3 セクションの塊状石灰 岩および周辺の塊状珪質石灰岩に含まれるオーイ ドも，水深が極めて浅い水の動きの活発な場で形 成されたと推定される。

なお, 塊状石灰岩中に部分的にチャートノ ジュールが認められるが,このチャート中には初 生的な内部構造は認められない。このチャートは シリカの二次的な置換で形成されたノジュールと 考えられる。

以上のことから, KR-1 セクションおよび KR-3 セクションの石灰岩は, いずれも極めて浅い海底 で堆積したと推定される。とくに堆積基盤が海洋 島玄武岩であることから, Baratal 石灰岩の一部 は過去の海洋域に存在した海台/海山頂部の孤立 型プラットフォームで初生的に堆積した遠洋浅海 性石灰岩であると判断される。

\section{3）古海台 / 海山斜面崩壊堆積物}

\section{〔石灰岩砂岩〕}

上述のクライ地域の KR-1 および KR-3 セク ションの例とは異なり, KR-2 セクションおよび アッカヤ地域の AK-1 および AK-2 セクションは 主に石灰岩碟岩からなる。石灰岩磁岩は塊状で, 明暸な層理や級化構造を持たない。礫のほとんど が $2 \mathrm{~mm} \sim 1 \mathrm{~cm}$ 径の角砂からなり, 礫の分級は 極めて悪い。また礫支持の部分が多いが, 部分的 に lime mudstone や ooid packstone からなる基 質によって支持されている。これらの特徽は, 斜 面崩壊などによって生じる土石流堆積物の特徵に 類似する。現世の炭酸塩プラットフォームの斜面 
下部や麓では, 石灰岩礫を主とする土石流堆積物 が観察され (Cook and Mullins, 1983 など), 本 地域の石灰岩礫岩は, それらによく類似する。

また，これらの石灰岩砂岩には，礫および基質 を問わず，石英・長石質の陸源粗粒砕屑物を全く 含まない。この事実は, これらの石灰岩礫が陸域 から十分距離がある遠洋域で, ほぼ石灰岩のみが 露出する場で削剥され, 礫岩として堆積したこと を示す。

AK-1 およびAK-2 セクションの石灰岩角礫岩 は ooid packstone を基質に持ち, その石灰岩角碟 の $80 \%$ 以上（体積比）はオーイドを含む wackestone および packstone からなる。また，少量 の緑色岩礫（体積比約 $2 \sim 15 \%$ ）を伴う。比較的

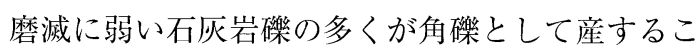
とから, 礫岩の堆積場は, 礫の供給源となった石 灰岩の露出地から極めて近距離にあったと推定さ れる。また，石灰岩礫は岩質とくにオーイドを含 む点で, 上述のクライ地域の KR-1 および KR-3 クションの石灰岩に酷似する。石灰岩礫の供給源 は, おそらく KR-1 および KR-3 セクションの石灰 岩と同一の起源を持つ古海台/海台上の孤立型炭 酸塩岩プラットフォームの一部と考えられる。以 上のことから, これらの石灰岩角礫岩は海洋中央 部の古海台/海山頂部で形成された孤立型炭酸塩 岩プラットフォームの石灰岩が削剥され, その近 傍で土石流堆積物として堆積したものと評価され る。少量含まれる緑色岩礫も, 同様にプラット フォームの基盤をなす古海台/海山の玄武岩から 由来したと推定される。

孤立した海山に関連する例としては, 日本の石 炭・ペルム系秋吉台石灰岩 (Sano and Kanmera, 1988), 帝釈台石灰岩（長谷ほか, 1974）, および 白木谷石灰岩（磯㠃, 1986）について, 同様の海 山斜面/麓に堆積した石灰岩礫岩が報告されている。 [スランプ堆積物]

クライ地域 KR-2 セクションの層状石灰岩の少 なくとも 3 層準には, 層内褶曲が認められる(図 7, 図 8 (b))。それらの層は, 側方連続せず, 分断さ れていることが多い。また，それらの層の上下の 地層は褶曲していない。したがって, この褶曲は
不安定な斜面などで堆積物が未固結〜半固結状態 で, 側方移動する際に形成される, スランプ構造 であると判断される。グレートバハマバンクでは, 礁の外側斜面に現世のスランプ堆積物が形成され ており，とくに傾斜の大きな斜面頂部付近に特徴 的に見られる（Mullins and Neumann, 1979）。

KR-2 セクションの層状石灰岩も古海台起原の 緑色岩の上に累重することから, 石灰岩礫岩と同 様に古海台の斜面とくに, その上部で堆積したと 推定される。

〔石灰岩タービダイト】

AK-3 セクションの上部の石灰岩は, 明瞭な層理 を持つ lime mudstone からなる。細粒で mm オーダーの層理を持つことから，上述の塊状石灰 岩や石灰岩碟岩などとは明瞭に異なる。この層状 石灰岩の内部堆積構造は鏡下観察でも不明暸で, その堆積場を推定する証拠にそしい。ただし,こ の lime mudstone からなる層状石灰岩は石灰岩 鿬岩と密接に産することから, おそらく不安定な 斜面に堆積した地層の一部と推定される。バハマ 諸島のエクスマ海峡やリトルバハマバンク東部で は, 現世の石灰岩タービダイトが観察されている。 それらは，石英・長石質タービダイトと同様に， 鮮明な底面や, 正級化, 平行葉理, およびクロス ラミナで特徴付けられるバウマ・シークェンスを 示す (Cook and Mullins, 1983)。一般に, 供給 源に近い場で堆積するタービダイト（proximal part）は粒度が磁〜砂サイズと粗く, 単層厚も大 きい。これに対して, 供給源から遠い場に堆積す るタービダイト（distal part）は泥サイズの粒子 から構成され，かつ単層厚が小さい。 AK-3 セク ション上部は, このような石灰岩タービダイトの distal partに対応する可能性がある。

過去の古海山起源石灰岩タービダイト（allodapic limestone) の例として, Isozaki (1987) は 礁性石灰岩起源礫を主体とするとするペルム系石 灰岩䃇岩を報告し，その一部をタービダイトの粗 粒部と認定した上で, その堆積場を古海山斜面の 下底周辺と推定した。

\section{4）古海山上および周辺の炭酸塩複合体の復元}

上述のように，クライ地域およびアッカヤ地域 

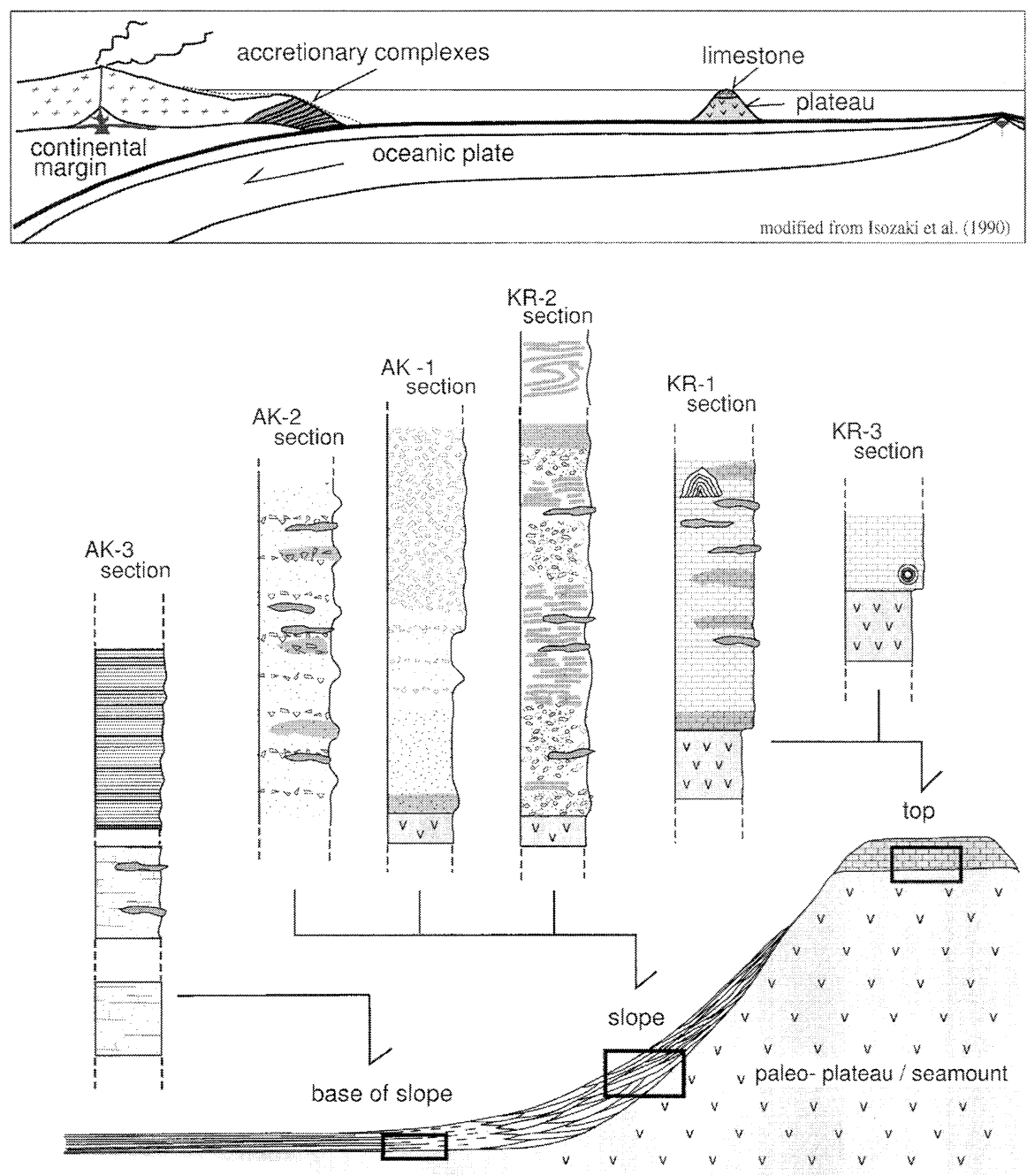

\begin{tabular}{|c|c|c|c|c|c|c|}
\hline 0 & ooid & ? & $\begin{array}{l}\text { brownish gray bedded } \\
\text { lime mudstone }\end{array}$ & 68. limestone breccia & $\square$ & carbonaceous part \\
\hline 4 & stromatolite & 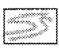 & $\begin{array}{l}\text { brownish gray slumped } \\
\text { bedded lime mudstone }\end{array}$ & laminated & 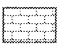 & massive lime mudstone \\
\hline$\infty$ & chert nodule & 80.8 & $\begin{array}{l}\text { massive } \\
\text { conglomerate }\end{array}$ & $\begin{array}{l}\text { poorly bedded } \\
\text { lime mudstone }\end{array}$ & $v_{v}$ & basaltic greenstone \\
\hline
\end{tabular}

図 14 Kurai 地域および Akkaya 地域の石灰岩の初生的堆積場の復元図.

Fig. 14 Schematic sedimentary environments of limestone in the Kurai and Akkaya areas.

の Baratal 石灰岩の初生的形成場としては，海台 や海山のような海洋中に存在した地形的高まりの 周辺およびその外洋側斜面ないし斜面麓が推定さ れる。両地域の石灰岩岩体を過去の同一の海台 / 海山起源であると仮定した上で，復元した各石灰
岩の堆積場を図 14 に示す。KR-1 および KR-3 セ クションの塊状石灰岩は古海台/海山頂部で，一 方，KR-2，AK-1 および AK-2 セクションの石灰 岩礫岩およびスランプ構造を持つ層状石灰岩は, 古海台/海山の斜面で堆積したと推定される。ま 
た, AK-3セクションの石灰岩タービダイトに比 較される石灰岩は, 古海台海山上の炭酸塩形成場 から比較的離れた斜面に堆積したと推定される。

ちなみに, 今回検討した 2 地域は互いに約 40 $\mathrm{km}$ 離れているが, 両地域の付加体ならびに緑色 岩・石灰岩岩体は, 地体構造的に連続している。 したがって，両地域の石灰岩および緑色岩は，お そらく同一の，あるいは少なくとも互いに隣接し ていた海台海山に起源を持つと考えられる。

過去の海山頂部の浅海相から斜面相を経て, 海 山麓の相に至る連続的な岩相の側方变化が解析さ れた例は, 日本の古生代および中生代付加体中の 石炭・ペルム紀石灰岩から多数報告されている（磯 㠃, 1985; Sano and Kanmera, 1988)。しかし, これまで先カンブリア時代の例は報告されておら ず，本研究で示したベンド紀の古海台頂部プラッ トフォーム複合体はこれまでの最古の例にあたる。 本研究結果は, さらに古い先カンブリア時代の例 についても同様な解析の可能性を強く示唆するも のである。

\section{VII. おわりに}

ロシア南部ゴルニアルタイ山地のカンブリア紀 付加体中に産する Baratal 石灰岩の岩相層序を解 析することによって, 以下のことが明らかとなっ た。

1）Baratal 石灰岩は, 遠洋域に存在した古海台 （あるいは海山）の頂部の玄武岩上に堆積した孤 立型炭酸塩岩プラットフォームの一部とみなさ れる。

2) Baratal 石灰岩は, ストロマトライトやオーラ イトを含む塊状石灰岩, 石灰岩角磥岩, スラン プ石灰岩および層状石灰岩タービダイトからな る。

3) ストロマトライトやオーライトを含む (浅海成) 塊状石灰岩は古海台の頂部, 石灰岩砂岩, スラ ンプ構造を持つ石灰岩および層状石灰岩タービ ダイトは, 古海台の側斜面および斜面麓に堆積 したと推定される。

本研究で示されたように，すでにマントルに沈 み込んでほとんどが消失した古海台/海山の山体
を復元する方法は，6 億年前よりもさらに古い過 去にも適用の可能性を持つと考えられる。

約 5 億 4,300 万年前の原生代/顕生代境界, 寸 なわちベンド紀/カンブリア紀境界（以後 V/C 境 界と表記）において, エデイアカラ動物群からカ ンブリア紀型動物群への大きな動物群の入れ代わ りが起きた（例えば, Cowie and Brasier, 1989; Sepkoski, 1992; Hallam and Wignall, 1997, 24-38; Narbonne, 1998)。これまで, 顕生代の生 物進化の方向性を決定付けた V/C 境界付近の地球 的規模環境変動を解明するため, ロシア・シベリア, 中国・雲南省, カナダ・ニューファンドランド, ナミビア等に産する陸棚相浅海成層を対象とした 研究が進められてきた。しかし，V/C 境界当時に 存在した海洋プレートはすべて過去のプレート収 束境界ですでにマントルに沈み込み, 現在の海洋 域には残されておらず，地球表層の約 70\%を占め ていた当時の海洋域についてのデータはこれまで 全く入手できなかった。

本研究で扱った Baratal 石灰岩は, V/C 境界付 近の遠洋域における浅海環境情報を保存している ことから, その層序・堆積環境が持つ意味は重要 である。筆者らは, 本研究で明らかにされた初生 層序に基づき，同石灰岩の全岩 $\mathrm{Pb}-\mathrm{Pb}$ アイソクロ ン年代測定による放射性年代決定や, ストロンチ ウムおよび炭素の同位体比の経年変動の解析を進 めており，それらの結果は別途報告の予定である。

\section{謝 辞}

本研究を進める上で, 現地調查の際には, Nikolai N. Semakov 博士，および Inna Y. Saphonova 氏をはじめ ロシア総合地質研究所シベリア支部の多くのスタッフの 方々に御協力頂いた。また, 鹿児島大学理学部の山本啓司 博士, 東京工業大学理学部の石川 晃博士（現: 岡山大 学固体地球研究センター), 金子慶之博士 (現: 横浜国 立大学環境情報研究院), 北島宏輝博士および片山郁夫 博士（現：Yale 大学）には野外・室内研究において指導 および御協力頂いた。産業技術総合研究所 (地質調查所) 西村 昭博士および中澤 努博士には多くの有益な助言 を頂いた。上記の方々に深く感謝する。

調查には, 平成 10 年 12 年度科学技術振興調整費 「全地球ダイナミクス:中心核にいたる地球システムの変 
動原理の解明に関する国際研究」および, 平成 13 年度 文部科学省科学研究費補助金 (特定領域研究 B) (研究課 題番号：12126202）を使用した。

ロシア・アルタイ山地において日本人として初めて本 格的な野外調查研究を推進しながら, 2002 年 5 月に急逝 された北海道大学渡辺暉夫教授にこの論文を捧げる。

\section{文献}

Afonin, A.I. (1976): The conjectural skeletal protospongia and chancelloria faunas from the Precambrian rocks of the Gorny Altai. Geol. Geophys., 11, 16-21. (in Russian)

Argand, E. (1924): La tectonique de l'Asie. Congres Geologique International (Brussel), Comptes Rendus de la VIII Session, premier fascicule. Vaillant-Carmanne, 171-372.

Buslov, M.M. and Watanabe, T. (1996): Intrasubduction collision and role in the evolution of an accretionary wedge: The Kurai zone of Gorny Altai. Russian Geol. Geophys., 37, 74-84.

Buslov, M.M., Bersin, N.A., Dobretsov, N.L. and Simonov, V.A. (1993): Geology and Tectonics of Gorny Altai. Guidebook, $4^{\text {th }}$ Intern. Symp. IGCP Project 283, "Geodynamic Evolution of the Paleoasian Ocean”. Rus. Acad. Sci. Siberian Branch.

Cook, H.E. and Mullins, H.T. (1983): Basin margin environment. In Scholle, P.A., Bebout, D.G. and Moore, C.H. eds.: Carbonate Depositional Environments. Mem. Amer. Assoc. Petrol. Geol., 33, 539-617.

Cowie, J.W. and Brasier, M.D. eds. (1989): The Precambrian-Cambrian Boundary. Oxford Monogr. Geol. Geophys., 12, Clarendon Press, Oxford.

Dunham, R.J. (1962): Classification of carbonate rocks according to depositional texture. In. Ham, W.E. ed.: Classification of Carbonate Rocks. Mem. Amer. Assoc. Petrol. Geol., 1, 108-121.

Gusev, N.I. (1991): Reconstruction of geodynamic regimes of Precambrian and Cambrian volcanism in the southeastern part of Gorny-Altai. Paleodynamics and Origin of South Siberian Perspective Zones. UIGG\&M SBRAS, 32-55. (in Russian)

Hallam, A. and Wignall, P.B. (1997): Mass Extinctions and Their Aftermath. Oxford University Press.

Halley, R.B., Harris, P.M. and Hine, A.C. (1983): Bank margin environment. In Scholle, P.A., Bebout, D.G. and Moor, C.H. eds.: Carbonate Depositional Environments. Mem. Amer. Assoc. Petrol. Geol., 33, 463-506.

長谷 晃・沖村雄二・横山鶴雄 (1974): 帝釈台とその 周辺の古生層, とくに石灰岩層の堆積相について. 広 島大学地学研究報告, 19, 1-39.

磯㟝行雄 (1985)：休場碟岩とその産状. 地質学雑誌, 91,
$535-551$.

磯㟝行雄 (1986): 秩父累帯北帯新改層とペルム紀末の 黒瀬川地塊北縁収束域. 地質学雑誌, 92, 497-516.

Isozaki, Y. (1987): End-permian convergent zone along the northern margin of Kurosegawa landmass and its products in central Shikoku, Southwest Japan. J. Geosci. Osaka City Univ., 30, 51-131.

磯㟝行雄 (1997): 超海洋中央部の P-T 境界危機一古海 山頂部の石灰岩の記録一. 神奈川県立博物館調查研究 報告, 8, 117-130.

Isozaki, Y., Maruyama, S. and Fukuoka, F. (1990): Accreted oceanic materials in Japan. Tectonophysics, 181, 179-205.

Kanmera, K. and Nishi, H.(1983): Accreted oceanic reef complex in Southwest Japan. In Hashimoto, M. and Uyeda, S. eds. : Accretion Tectonics in the Circum-Pacific Region. TERRAPUB, 195-206.

Major, R.P., Bebout, D.G. and Harris, P.M. (1996): Recent evolution of a Bahama ooid shoal : Effects of Hurricane Andrew. Bull. Geol. Soc. Am., 108, 168-180.

Maruyama, S., Liou, J.G. and Seno, T. (1989): Mesozoic and Cenozoic evoution of Asia. In BenAvraham, Z. ed.: The Evolution of the Pacific Ocean Margins. Oxford Monogr. Geol. Geophys., 8, Clarendon Press, 75-99.

Mullins, H.T. and Neumann, A.C. (1979): Deep carbonate bank margin structure and sedimentation in the northern Bahamas, In Doyle, L.J. and Pilkey, D.H. eds. : Geology of Continental Slopes. SEPM Spec. Publ., 27, 165-192.

Narbonne, G.M. (1998): The Ediacara biota: A terminal Neoproterozoic experiment in the evolution of life. GSA Today, 8(2), 1-6.

太田彩乃・勘米良亀齢・磯嵭行雄 (2000): 宮崎県高千 穂町上村のペルム系岩戸層および三田井層の層序：海 山頂部相石灰岩中に確認された茅口階, 呉家坪階およ び長興階. 地質学雑誌， 106, 853-864.

太田正道 (1968): 地向斜型生物礁複合体としての秋吉 石灰岩層群。秋吉台科学博物館報告， 5, 1-44.

Reid, R.P., Macintyre, I.G., Browne, K.M., Steneck, R.S. and Miller, T. (1995): Stromatolites in the Exuma Cays, Bahamas: Uncommonly common. Facies, 33, 1-18.

Reither, S., Arp, G., Thiel, V., Gautret, P., Galling, U. and Michealsis, W. (1997): Organic matter in Great Salt Lake ooids (Utah, USA) First approach to a formation via organic matrices. Facies, 36, 210-219.

Riding, R. (2002): Structure and composition of organic reefs and carbonate mud mound: Concept and categories. Earth Sci. Rev., 58, 163-231.

Sano, H. and Kanmera, K. (1988): Paleogeographic reconstruction of accreted oceanic rocks, Akiyoshi, southwest Japan. Geology, 16, 600-603.

Sengör, A.M.C. and Natalin, B. (1996): Paleotecton- 
ics of Asia: Fragments of a synthesis. In Yin, A. and Harrison, M. eds.: The Tectonic Evolution of Asia. Cambridge Univ. Press, 486-640.

Seong-Joo, L., Browne, K.M. and Golubic, S. (2000): On stromatolite lamination. In Riding, $\mathrm{R}$. and Awramik, S. M. eds. : Microbial Sediments. Springer-Verlag, 16-24.

Sepkoski, J.J. (1992): Proterozoic-Early Cambrian diversification of metazoans and metaphytes. In Schop, J.W. and Klein, C. eds.: The Proterozoic Biosphere. Cambridge University Press, 553-561.

内尾優子·磯㟝行雄・太田 努・ 丸山茂徳·Buslov, M.M. (1998): ベンド紀・カンブリア紀海山頂部石灰岩の産 状と岩相一シベリア南部ゴルニアルタイ地域の例一. 月刊地球, 20, 695-698.
宇都宮 敦・太田 努·石川 晃・丸山茂徳・Buslov, M.M. (1998): シベリアクラトン南縁部カンブリア紀 付加体に産する緑色岩の岩石学. 日本地質学会第 105 年学術大会講演要旨, 223 .

Zonenshain, L.P. (1973): The evolution of central Asiatic geosynclines through sea-floor spreading. Tectonophysics, 19, 213-232.

Zybin, V.A. and Sergeev, V.P.(1978): Upper Proterozoic stratigraphy of the southeastern Altai. New Data in Late Precambrian Stratigraphy and Paleontology of the Altai-Sayan Fold Area and Tuva. Institute of Geology and Geophysics AN SSR, 9-22.

(2003 年 3 月 24 日受付, 2003 年 7 月 22 日受理) 